\title{
Voltage-gated and $\mathrm{Ca}^{2+}$-activated $\mathrm{K}^{+}$ Channels in Intact Human T Lymphocytes
}

\author{
Noninvasive Measurements of Membrane Currents, \\ Membrane Potential, and Intracellular Calcium
}

\author{
Jos A. H. Verheugen, Henk P. M. Vijverberg, Marga Oortgiesen, \\ and Michael D. CahalaN* \\ From the Research Institute of Toxicology, Utrecht University, NL-3508 TD Utrecht, The \\ Netherlands; and *Department of Physiology and Biophysics, University of California at \\ Irvine, Irvine, California 92717
}

\begin{abstract}
Voltage-gated $n$-type $\mathrm{K}(V)$ and $\mathrm{Ca}^{2+}$-activated $\mathrm{K}^{+}[\mathrm{K}(\mathrm{Ca})]$ channels were studied in cell-attached patches of activated human $T$ lymphocytes. The single-channel conductance of the $\mathrm{K}(V)$ channel near the resting membrane potential $\left(V_{\mathrm{m}}\right)$ was $10 \mathrm{pS}$ with low $\mathrm{K}^{+}$solution in the pipette, and $33 \mathrm{pS}$ with high $\mathrm{K}^{+}$ solution in the pipette. With high $\mathrm{K}^{+}$pipette solution, the channel showed inward rectification at positive potentials. $K(V)$ channels in cell-attached patches of $T$ lymphocytes inactivated more slowly than $\mathrm{K}(V)$ channels in the whole-cell configuration. In intact cells, steady state inactivation at the resting membrane potential was incomplete, and the threshold for activation was close to $V_{m}$. This indicates that the $\mathrm{K}(V)$ channel is active in the physiological $V_{\mathrm{m}}$ range. An accurate, quantitative measure for $V_{\mathrm{m}}$ was obtained from the reversal potential of the $\mathrm{K}(V)$ current evoked by ramp stimulation in cell-attached patches, with high $\mathrm{K}^{+}$solution in the pipette. This method yielded an average resting $V_{\mathrm{m}}$ for activated human $T$ lymphocytes of $-59 \mathrm{mV}$. Fluctuations in $V_{\mathrm{m}}$ were detected from changes in the reversal potential. Ionomycin activates $\mathrm{K}(\mathrm{Ca})$ channels and hyperpolarizes $V_{\mathrm{m}}$ to the Nernst potential for $\mathrm{K}^{+}$. Elevating intracellular $\mathrm{Ca}^{2+}$ concentration $\left(\left[\mathrm{Ca}^{2+}\right]_{\mathrm{i}}\right)$ by ionomycin opened a 33-50-pS channel, identified kinetically as the CTX-sensitive IK-type $\mathrm{K}(\mathrm{Ca})$ channel. The $\mathrm{Ca}^{2+}$ sensitivity of the $\mathrm{K}(\mathrm{Ca})$ channel in intact cells was determined by measuring $\left[\mathrm{Ca}^{2+}\right]_{i}$ and the activity of single $\mathrm{K}(\mathrm{Ca})$ channels simultaneously. The threshold for activation was between 100 and $200 \mathrm{nM}$; half-maximal activation occurred at $450 \mathrm{nM}$. At concentrations $>1 \mu \mathrm{M}$, channel activity decreased. Stimulation of the T-cell receptor/CD3 complex using the mitogenic lectin, PHA, increased $\left[\mathrm{Ca}^{2+}\right]_{i}$, and increased channel activity and current amplitude resulting from membrane hyperpolarization.
\end{abstract}

Address correspondence to Michael D. Cahalan, Department of Physiology and Biophysics, UCI, Irvine CA 92717.

J. Gen. Physiol. (T) The Rockefeller University Press $\cdot 0022-1295 / 95 / 06 / 0765 / 30 \$ 2.00$ 
I N T ROD U C TION

The predominant ion conductance in resting human lymphocytes is a voltage-gated $\mathrm{K}^{+}[\mathrm{K}(V)]$ channel, type $n$ (DeCoursey, Chandy, Gupta, and Cahalan, 1984; Cahalan, Chandy, DeCoursey and Gupta, 1985). This channel has been identified as the cloned $\mathrm{K}^{+}$channel $\mathrm{K}_{\mathrm{v}} 1.3$ (Cai, Osborne, North, Dooley, and Douglass, 1992; Grissmer, Dethlefs, Goldin, Gutman, Cahalan, and Chandy, 1990; Attali, Romey, Honoré, Schmid-Alliana, Mattéi, Lesage, Ricard, Barhanin, and Lazdunski, 1992b), according to the nomenclature proposed by Chandy (1991). The $K(V)$ channel is involved in setting the membrane potential, $V_{m}$, of human $\mathrm{T}$ lymphocytes (Grinstein and Smith, 1990; Leonard, Garcia, Slaughter and Reuben, 1992). In addition, the $\mathrm{K}(V)$ channel may participate in volume regulation in response to osmotic shock (Cahalan and Lewis, 1988, 1990; Deutsch and Chen, 1993; Grinstein and Smith, 1990).

The electrophysiology of the $n$-type $\mathrm{K}(V)$ channel has been well characterized in whole-cell patch clamp experiments (DeCoursey et al., 1984; Matteson and Deutsch, 1984; Cahalan et al., 1985; DeCoursey, Chandy, Gupta, and Cahalan, 1985; Sands, Lewis, and Cahalan, 1989; Pahapill and Schlichter, 1990; Verheugen, Oortgiesen, and Vijverberg, 1994c). Under whole-cell patch-clamp conditions, $\mathrm{K}(V)$ current has a threshold for activation of -40 to $-50 \mathrm{mV}$ and a maximum conductance $>\sim 0 \mathrm{mV}$. During prolonged depolarization, the current inactivates with a time constant of $\sim 180 \mathrm{~ms}$. The $\mathrm{K}(V)$ channel exhibits pronounced steady state inactivation at -40 $\mathrm{mV}$ and recovery from inactivation is slow. Modulation of the $n$-type $\mathrm{K}(\mathrm{V})$ current by pH, cAMP and $\mathrm{Ca}^{2+}$ has been reported (see for review: Gallin, 1991). A possible mechanism for altering properties of the $n$-type $\mathrm{K}(V)$ current is the phosphorylation and dephosphorylation of the $K_{\mathrm{v}} 1.3$ channel protein (Cai and Douglass, 1993).

Intracellular signal transduction is likely to be affected after break in to the whole-cell configuration. To understand the role of the $\mathrm{K}(V)$ channel in lymphocyte functioning, it is crucial to determine the characteristics of this channel under conditions as close to the physiological situation as possible. This can be achieved by using patch clamp techniques in the cell-attached configuration which leaves the cytoplasmic environment unaltered and allows physiological membrane-potential fluctuations. Electrophysiological data on the $\mathrm{K}(V)$ channel in intact T lymphocytes are scarce, and have been reported only in resting $\mathrm{T}$ lymphocytes (Lee, Levy, and Deutsch, 1992; Pahapill and Schlichter, 1992).

Stimulation of $\mathrm{T}$ lymphocytes via the T-cell receptor/CD3 complex by specific antigen or nonspecific mitogens such as phytohemagglutinin (PHA) initiates a series of intracellular events, ultimately leading to cell proliferation. Among the earliest cellular responses are increased phosphatidylinositol turnover, and a transient, often oscillating, elevation of $\left[\mathrm{Ca}^{2+}\right]_{\mathrm{i}}$ (Lewis and Cahalan, 1989; Hess, Oortgiesen, and Cahalan, 1993). Part of the $\mathrm{Ca}^{2+}$ signal depends on $\mathrm{Ca}^{2+}$ influx from the extracellular solution. Because the membrane potential determines the electrochemical driving force for ion flux, regulation of the membrane potential is likely to be important for lymphocyte activation. Elevating extracellular $\left[\mathrm{K}^{+}\right]$causes membrane depolarization and subsequent inhibition of the $\mathrm{Ca}^{2+}$ signal generated in response to activation of the T-cell receptor/CD3 complex (Gelfand, Cheung, and Grinstein, 1984; Oettgen, 
Terhorst, Cantley, and Rosoff, 1985; Lewis and Cahalan, 1989; Hess et al., 1993). Blockers of the $\mathrm{K}(V)$ channel inhibit the proliferation of $\mathrm{T}$ and $\mathrm{B}$ lymphocytes after mitogenic stimulation (Chandy, DeCoursey, Cahalan, McLaughlin, and Gupta, 1984; DeCoursey et al., 1984; Deutsch, Krause, and Lee, 1986; Amigorena, Choquet, Teillaud, Korn, and Fridman, 1990). It seems likely that the effect of $K(V)$-channel blockers on proliferation results from inhibition of the early $\mathrm{Ca}^{2+}$ signal. Lin, Boltz, Blake, Nguyen, Talento, Fischer, Springer, Sigal, Slaughter, Garcia, Kaczorowski, and Koo (1993) demonstrated a direct inhibition of the $\mathrm{Ca}^{2+}$ signal by charybdotoxin, which blocks both $\mathrm{K}(V)$ and $\mathrm{K}(\mathrm{Ca})$ channels, and by selective blockers of the $\mathrm{K}(V)$ channel, noxiustoxin and margatoxin. Although conflicting data have been reported, $V_{m}$ hyperpolarizes immediately after mitogenic stimulation, as $\mathrm{Ca}^{2+}$ dependent $\mathrm{K}^{+}[\mathrm{K}(\mathrm{Ca})]$ channels open secondary to a ligand-induced increase in $\left[\mathrm{Ca}^{2+}\right]_{\mathrm{i}}$ (reviewed in Grinstein and Dixon, 1989). Recently, a $\mathrm{K}(\mathrm{Ca})$ channel in human $\mathrm{T}$ lymphocytes was characterized in excised patches and whole-cell experiments (Grissmer, Nguyen, and Cahalan, 1993; Verheugen, van Kleef, Oortgiesen, and Vijverberg, 1994a). The single-channel conductance of 30-60 pS, lack of voltage dependence, block by charybdotoxin (CTX), and resistance to apamin classify this channel as an IK-type $\mathrm{K}(\mathrm{Ca})$ channel (Dreyer, 1990). Hyperpolarization provided by the opening of $\mathrm{K}(\mathrm{Ca})$ channels may also contribute to the oscillatory $\mathrm{Ca}^{2+}$ signal in peripheral blood lymphocytes (Verheugen and Vijverberg, 1995). In Jurkat $T$ cells, such oscillations are attenuated by blocking both $\mathrm{K}(V)$ and $\mathrm{K}(\mathrm{Ca})$ channels but not by blocking either channel type alone (Grissmer, Lewis, and Cahalan, 1992).

Mitogenic stimulation of lymphocytes by lectins such as PHA or concanavalin A also enhances expression of both $\mathrm{K}(V)$ and $\mathrm{K}(\mathrm{Ca})$ channels. In whole-cell patch clamp experiments, two- to threefold increases in $\mathrm{K}(V)$ conductance in human $\mathrm{T}$ lymphocytes (Deutsch et al., 1986; Grissmer et al., 1993) to more than 10-fold in murine $T$ lymphocytes (DeCoursey, Chandy, Gupta, and Cahalan, 1987) and human B lymphocytes (Amigorena et al., 1990; Partiseti, Choquet, Diu, and Korn, 1992; Partiseti, Korn, and Choquet, 1993) have been measured 1-2 d after mitogenic stimulation. The whole-cell $\mathrm{K}(\mathrm{Ca})$ conductance is $<0.5 \mathrm{nS}$ in resting $\mathrm{T}$ cells, but averages $6.4 \mathrm{nS}$ in cells treated with PHA for $>2 \mathrm{~d}$ (Grissmer et al., 1993). As a result, in excised patches of resting $T$ lymphocytes, $\mathrm{K}(\mathrm{Ca})$ channels are seen only occasionally, whereas large numbers of $\mathrm{K}(\mathrm{Ca})$ channels are observed in excised patches of chronically PHA-stimulated T lymphocytes (Verheugen et al., 1994a). In human B lymphocytes, a similar increase in the number of $\mathrm{K}(\mathrm{Ca})$ channels occurs after activation (Partiseti et al., 1992, 1993).

In activated lymphocytes, the increased expression of $\mathrm{K}^{+}$channels makes it feasible to study $\mathbf{K}(V)$ and $\mathbf{K}(\mathrm{Ca})$ channel properties in membrane patches. Therefore, we examined the characteristics of $\mathrm{K}(V)$ channels in cell-attached patches of activated human $\mathrm{T}$ lymphocytes. Furthermore, we show that the $\mathrm{K}(V)$ current elicited by voltage ramps can be used to monitor the membrane potential of intact cells. We also describe the behavior of $\mathrm{K}(\mathrm{Ca})$ channels in intact activated human $\mathrm{T}$ lymphocytes, using the cell-attached patch clamp technique in combination with fura-2 measurements of $\left[\mathrm{Ca}^{2+}\right]_{\mathrm{i}}$. The correlation between $\left[\mathrm{Ca}^{2+}\right]_{i}, \mathrm{~K}(\mathrm{Ca})$ channel activity, and membrane potential in response to activation of the T-cell receptor/CD3 complex is demonstrated by recording single-channel currents and simultaneously measuring 
$\left[\mathrm{Ca}^{2+}\right]_{\mathrm{i}}$ during acute PHA stimulation. A preliminary report has appeared (Verheugen, Oortgiesen, and Cahalan, 1994b).

METHODS

Cell Culture

Lymphocytes were isolated from peripheral blood of healthy volunteers using the standard Ficoll-Paque sedimentation technique. The resulting cell population contained $>75 \% \mathrm{~T}$ cells as assessed by fluorescent labelling with $T$ cell specific markers (anti-CD3 or a combination of anti-CD4 and anti-CD8). Activated T lymphocytes were obtained by culturing freshly isolated cells in Dulbecco's modified Eagle medium (DMEM) supplemented with 10\% fetal calf serum (FCS) and the following amino acids (in millimolar): cysteine $\cdot \mathrm{HCl} \mathrm{0.3,} \mathrm{L-alanine} \mathrm{0.4,}$ L-asparagine 0.45, L-aspartic acid 0.4, L-proline 0.4, and L-glutamic acid 0.4 , and $1 \mu \mathrm{g} / \mathrm{ml} \mathrm{PHA}$ (Difco Laboratories, Detroit, MI, or Wellcome, Dartford, UK) at $37^{\circ} \mathrm{C}$ in a humified atmosphere containing $7.5 \% \mathrm{CO}_{2}$. After $2-3 \mathrm{~d}$ in culture, the medium was refreshed. In general, cells were used after $2-7 \mathrm{~d}$ in culture. Before the experiments, cells were diluted in low $\mathrm{K}^{+}$solution and allowed to settle for 5-10 min on a glass coverslip mounted in the bottom of a $35-\mathrm{mm}$ dish. Generally, the phenotype of the cell was determined at the end of the electrophysiological experiment. Results obtained with $\mathrm{CD}^{+}$and with $\mathrm{CD}^{+} \mathrm{T}$ cells were indistinguishable.

\section{Solutions}

The bath solution (low $\mathrm{K}^{+}$) contained (in millimolar): $160 \mathrm{NaCl}, 4.5 \mathrm{KCl}, 2 \mathrm{CaCl}_{2}, 1 \mathrm{MgCl}_{2}, 5$ HEPES, adjusted to $\mathrm{pH} 7.4$ with $\mathrm{NaOH}$ and to $310-330 \mathrm{mOsm}$ with sucrose. The pipette solution (high $\mathrm{K}^{+}$) contained (in millimolar): $160 \mathrm{KCl}, 2 \mathrm{CaCl}_{2}, 1 \mathrm{MgCl}_{2}, 10 \mathrm{HEPES}$, adjusted to $\mathrm{pH} 7.4$ with $\mathrm{KOH}$ and to $295-320 \mathrm{mOsm}$ with sucrose. Alternatively, a $\mathrm{Ca}^{2+}$-free high $\mathrm{K}^{+}$ pipette solution was used, containing (in millimolar): $150 \mathrm{KCl}, 5 \mathrm{HEPES}, 0.5 \mathrm{EGTA}$, adjusted to pH 7.2 with $\mathrm{KOH}$ and to 315 mOsm with sucrose. Some experiments were done with high $\mathrm{K}^{+}$ solution in the bath and/or low $\mathrm{K}^{+}$solution in the pipette, as indicated.

\section{Electrophysiology, Data Acquisition, and Analysis}

Currents were recorded in the cell-attached configuration (Hamill, Marty, Neher, Sakmann, and Sigworth, 1981) using an EPC-7 patch clamp amplifier (List Electronic, Darmstadt, Germany). Recording pipettes (Clark; GC150 borosilicate glass) with a resistance of 1-6 M $\Omega$ were used. Cells were placed on the stage of an inverted phase-contrast/fluorescent microscope (Carl Zeiss, Axiovert $35 \mathrm{M}$ ). A $0.5-\mathrm{mm}$ diam superfusion pipette was positioned $0.5 \mathrm{~mm}$ from the cell and connected to a four-way valve to allow switching between different solutions. Superfusion with a flow rate of $\sim 0.5 \mathrm{ml} / \mathrm{min}$ was started before voltage clamping the cell and was maintained throughout the experiment. Nomenclature: $V_{\mathrm{m}}$ is the membrane potential; $V_{\mathrm{h}}$ the holding potential $\left(-V_{\text {pipette }}\right)$; and $\left(V_{\mathrm{m}}+V_{\mathrm{h}}\right)$ the potential across the patch. After gigaseal formation, $V_{\mathrm{h}}$ was set to $0 \mathrm{mV}$ (i.e., only $V_{\mathrm{m}}$ is present across the patch) or to $-60 \mathrm{mV}$ (i.e., the patch potential is $60 \mathrm{mV}$ hyperpolarized with respect to $V_{\mathrm{m}}$ ). Voltage-gated currents were evoked by applying voltage ramps or depolarizing voltage steps. Unless stated otherwise, the stimulation interval was $20 \mathrm{~s}$, which was sufficient to allow for complete recovery from inactivation under all experimental conditions. The membrane currents were low-pass filtered $(-3 \mathrm{~dB}$ at $2 \mathrm{kHz} ; 12 \mathrm{~dB} /$ octave), digitized (12 bits; 1,024 points/record) and stored on magnetic disc for off-line computer analysis. For analysis of currents evoked by ramp stimulation, a correction was made for a leak component by linear extrapolation. In patches that did not contain channels, the leak was linear in the potential range from -100 to +200 
$\mathrm{mV}$. Current records obtained by voltage steps were corrected for leakage and capacitative currents by subtracting averaged records without channel openings. Single-channel amplitude was determined based on the peaks in an amplitude histogram. Curve fitting was performed using a Levenberg-Marquardt nonlinear least-squares algorithm (Marquardt, 1963). Current decay was fitted by the exponential function:

$$
i_{\mathrm{t}}=i_{\mathrm{oo}}+i_{0} \cdot e^{-\mathrm{t} / \tau}
$$

Simultaneous $\mathrm{Ca}^{2+}$ Measurements

$\left[\mathrm{Ca}^{2+}\right]_{i}$ was measured using the fluorescent $\mathrm{Ca}^{2+}$ probe fura-2 (Grynkiewicz, Poenie, and Tsien, 1985). Shortly before the experiment, cells were loaded with $1 \mu M$ fura-2/AM (Molecular Probes, Inc., Eugene, OR) in RPMI/ $10 \%$ FCS for $25 \mathrm{~min}$ in the dark at room temperature. The cells were washed twice with external solution and plated on a poly-L-lysine coated coverslip which was placed on the stage of an IM-35 inverted microscope (Carl-Zeiss, Oberkochen, Germany). After gigaseal formation, the attached cell was illuminated alternately at 350 and $385 \mathrm{~nm}$ using a Xenon arc light source. Fluorescence emission at $510 \mathrm{~nm}$ was collected with a photomultiplier tube (model 647-04, Hamamatsu Corp., Tokyo, Japan) and a photon-counting photometer (model 126, Pacific Instruments, Concord, CA) through a pinhole equal in size to the cell diameter. A $63 \times$ oil-immersion objective was used (Zeiss Neofluar, N.A. $=1.25$ ). The resulting signals were background-corrected, and $\left[\mathrm{Ca}^{2+}\right]$ was estimated using the equation

$$
\left[\mathrm{Ca}^{2+}\right]=K^{* \cdot}\left(R-R_{\min }\right) /\left(R_{\max }-R\right)
$$

where $K^{*}, R_{\min }$ and $R_{\max }$ were determined either by a solution calibration or by loading single cells with a zero $\mathrm{Ca}^{2+}$ solution (saline containing $10 \mathrm{mM}$ EGTA and no added $\mathrm{Ca}^{2+}$ ) and with a high $\mathrm{Ca}^{2+}$ solution (saline with $10 \mathrm{mM} \mathrm{CaCl}$ and no EGTA), respectively. Both the high and zero $\mathrm{Ca}^{2+}$ solutions contained $10 \% \mathrm{vol} / \mathrm{vol} 1 \mathrm{mM}$ fura- 2 salt. The resulting $K^{*}, R_{\max }$ and $R_{\min }$ values were similar for both methods. A $K_{\mathrm{d}}$ of $220 \mathrm{nM}$ for fura-2 was assumed.

The fluorescence signal and single-channel activity (250-ms current traces) were recorded every 2 s. All experiments were conducted at room temperature $\left(20-26^{\circ} \mathrm{C}\right)$.

\section{Single-Channel Data Analysis}

Single-channel data were stored on magnetic disc for off-line analysis. Transitions between open and closed states were detected using a half-amplitude threshold criterion and a minimum event width of $0.25 \mathrm{~ms}$. Total open probability $\left(N \cdot P_{\mathrm{o}}\right.$, in which $N$ is the number of channels in the patch) was quantified by integrating a current trace of $250 \mathrm{~ms}$, after leak subtraction, and normalizing the value with respect to the single-channel amplitude (which varies with $V_{\mathrm{m}}$ of the attached cell). Linearity and regression tests were performed by least-squares regression analysis (Diem and Lentner, 1971). Results are presented as mean \pm SD. Results were compared using the two-tailed $t$ test.

\section{R E S U L T S}

Channels were studied in cell-attached patches of PHA-activated human T lymphocytes with high or low $\mathrm{K}^{+}$pipette solution. Three types of channels were distinguished on the basis of the single-channel current amplitude, open lifetimes, and voltage dependence. A small channel with $1.5 \pm 0.2 \mathrm{pA}$ amplitude at a holding potential of $0 \mathrm{mV}$ was often active immediately after seal formation (Fig. $1 A$ ). The mean open time of the small channel was $7.4 \pm 5.2 \mathrm{~ms}(n=25)$. After $1-2 \mathrm{~min}$, its activity subsided; because of the transient nature of this activity, this channel could 


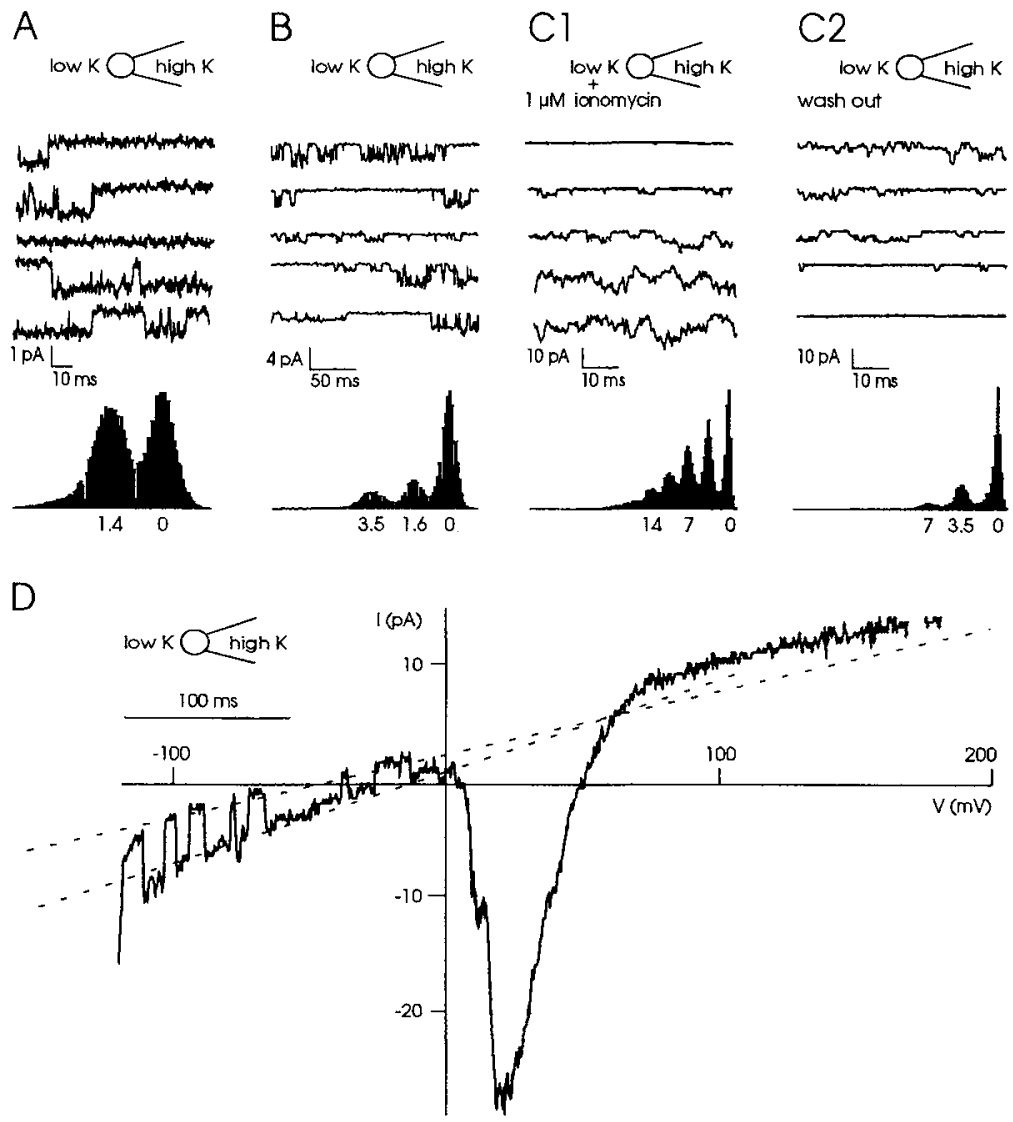

FIGURE 1. Characteristic single-channel activity in cell-attached patches of PHA-activated human $\mathrm{T}$ lymphocytes. The corresponding amplitude histograms are based on at least 50 current traces. $(A)$ Spontaneous activity of a small channel recorded shortly after gigaseal formation. Consecutive traces were recorded at a frequency of $5 \mathrm{~Hz}\left(V_{\mathrm{h}}=0 \mathrm{mV}\right)$. Typically, the activity of this channel subsided 1-2 min after gigaseal formation. In $\sim 50 \%$ of the cells, the activity of this smaller channel was followed by spontaneous activity of a larger channel. $(B)$ In some cells, simultaneous activity of both channels occurred for a short period (traces recorded at $0.5 \mathrm{~Hz}, V_{\mathrm{h}}=0 \mathrm{mV}$ ), after which activity of the larger channel prevailed. The spontaneous activity of this larger channel disappeared after $\sim 2 \mathrm{~min}$, but could be restored by application of ionomycin. $(C)$ Addition of $1 \mu \mathrm{M}$ ionomycin to the bath $(C 1)$ and return to control solution (C2). Traces were recorded with an interval of $2 \mathrm{~s}\left(V_{\mathrm{h}}=0 \mathrm{mV}\right)$. Note the different scales in $A, B$, and $C$. Open states of both channels are seen as downward deflections from the baseline. $(D)$ Currents evoked by a $500-\mathrm{ms}$ ramp stimulation from -120 to $+180 \mathrm{mV}$. The patch contains both $\mathrm{K}(\mathrm{Ca})$ and $\mathrm{K}(V)$ channels. The closed level of $\mathrm{K}(\mathrm{Ca})$ channels at negative potentials was used to determine the slope of a linear leak component. The potential where the voltage-gated component crossed the extrapolated leak component was assumed to be the reversal potential for $\mathrm{K}^{+}$. Because $E_{\mathrm{K}}$ across the patch is $\sim 0 \mathrm{mV}$, this potential is equal but opposite in sign to the cell membrane potential. 
not be analyzed in further detail. A second type of channel, having a larger amplitude and shorter open time, was sometimes spontaneously active after seal formation; simultaneous activity of both channels could usually be observed during a short period (Fig. $1 B$ ). The activity of the larger channel lasted for $\sim 3$ min. Although the activity of the larger channel was also transient, elevation of $\left[\mathrm{Ca}^{2+}\right]_{i}$ by ionomycin induced activity of a channel which was indistinguishable (Fig. $1 C$ ). Therefore, it was possible to study this channel in more detail and to identify it as an intermediateconductance $\mathrm{K}(\mathrm{Ca})$ channel described previously in excised patches of human $\mathrm{T}$ lymphocytes (Grissmer et al., 1993; Verheugen et al., 1994a). The third channel type, found in most cell-attached patches, was activated by patch depolarization and is identified as a type $n \mathrm{~K}(V)$ channel (Fig. $1 D$ ). Properties of $\mathrm{K}(V)$ and $\mathrm{K}(\mathrm{Ca})$ channels are described separately below.

\section{Voltage-gated $\mathrm{K}^{+}$Currents in Cell-attached Patches}

Applying depolarizing voltage steps from a $V_{\mathrm{h}}$ of $-60 \mathrm{mV}$ to cell-attached patches of activated human $T$ lymphocytes results in the activation of a voltage-gated ion channel. When the pipette contains low $\mathrm{K}^{+}$solution, the current is outward and increases gradually with membrane potential. With high $\mathrm{K}^{+}$solution in the pipette, the current is initially inward beyond the threshold for activation between $-10-0$ $\mathrm{mV}$, relative to $V_{\mathrm{m}}$. Discrete single-channel currents are observed close to the activation threshold, and at more positive potentials the total current becomes too large to distinguish discrete channel openings in most patches. After reaching a maximum, the current declines and reverses at a potential close to $+50 \mathrm{mV}$ (Fig. $2 \mathrm{~A}$ ). When the pipette contained a solution consisting of (in millimolar): $30 \mathrm{NaCl}, 5$ $\mathrm{CsCl}, 25 \mathrm{TEA}, 50 \mathrm{BaCl}_{2}, 2 \mathrm{CaCl}_{2}$ and 5 HEPES, which normally favors $\mathrm{Ca}^{2+}$ current, no inward current was observed, thereby excluding the possibility that (part of) the voltage-gated current is carried by $\mathrm{Ca}^{2+}$ (data not shown). The dependence on pipette $\mathrm{K}^{+}$concentration indicates that this current is mainly carried by $\mathrm{K}^{+}$. Estimates for $\left[\mathrm{K}^{+}\right]_{\mathrm{i}}$ in human $\mathrm{T}$ lymphocytes range between 130 and $150 \mathrm{mM}$ (Grinstein and Dixon, 1989). With high $\mathrm{K}^{+}$solution in the pipette, the theoretical reversal potential for $\mathrm{K}^{+}$current across the patch is close to $0 \mathrm{mV}$. Under these conditions the current will reverse when $V_{\mathrm{h}}$ cancels $V_{\mathrm{m}}$, (e.g., Fig. $2 A$, the reversal at $V_{\mathrm{h}}=-50 \mathrm{mV}$ indicates a $V_{\mathrm{m}}$ of $-50 \mathrm{mV}$ ).

The $\mathrm{K}(V)$ current inactivated during prolonged membrane depolarization (Fig. $2 A$ ). The rate of inactivation was estimated by fitting the currents with an exponential decay function. Reliable curve fitting was only possible for currents that were sufficiently large, i.e., at potentials beyond $+50 \mathrm{mV}$ with low $\mathrm{K}^{+}$solution in the pipette. The time constant of inactivation was $430 \pm 75 \mathrm{~ms}(n=7)$, with no clear voltage dependence in the potential range of +60 to $+140 \mathrm{mV}$. With high $\mathrm{K}^{+}$pipette solution, the time constant from 0 to $+20 \mathrm{mV}$ was $2.5 \pm 1.3 \mathrm{~s}(n=21)$. At higher potentials, the current was too small to fit.

Voltage ramps were applied to cell-attached patches of activated human $T$ lymphocytes to obtain $I-V$ relations. Voltage-gated $\mathrm{K}^{+}$current, superimposed on the leak current, was present in $\sim 80 \%$ of the parches (Fig. $2 \mathrm{~B}$ ). To resolve the various parameters of the voltage-gated current, a stimulation protocol was chosen in which the potential was ramped from -100 to $+200 \mathrm{mV}$ at a rate of $0.6 \mathrm{mV} / \mathrm{ms}$. A 20 -s 


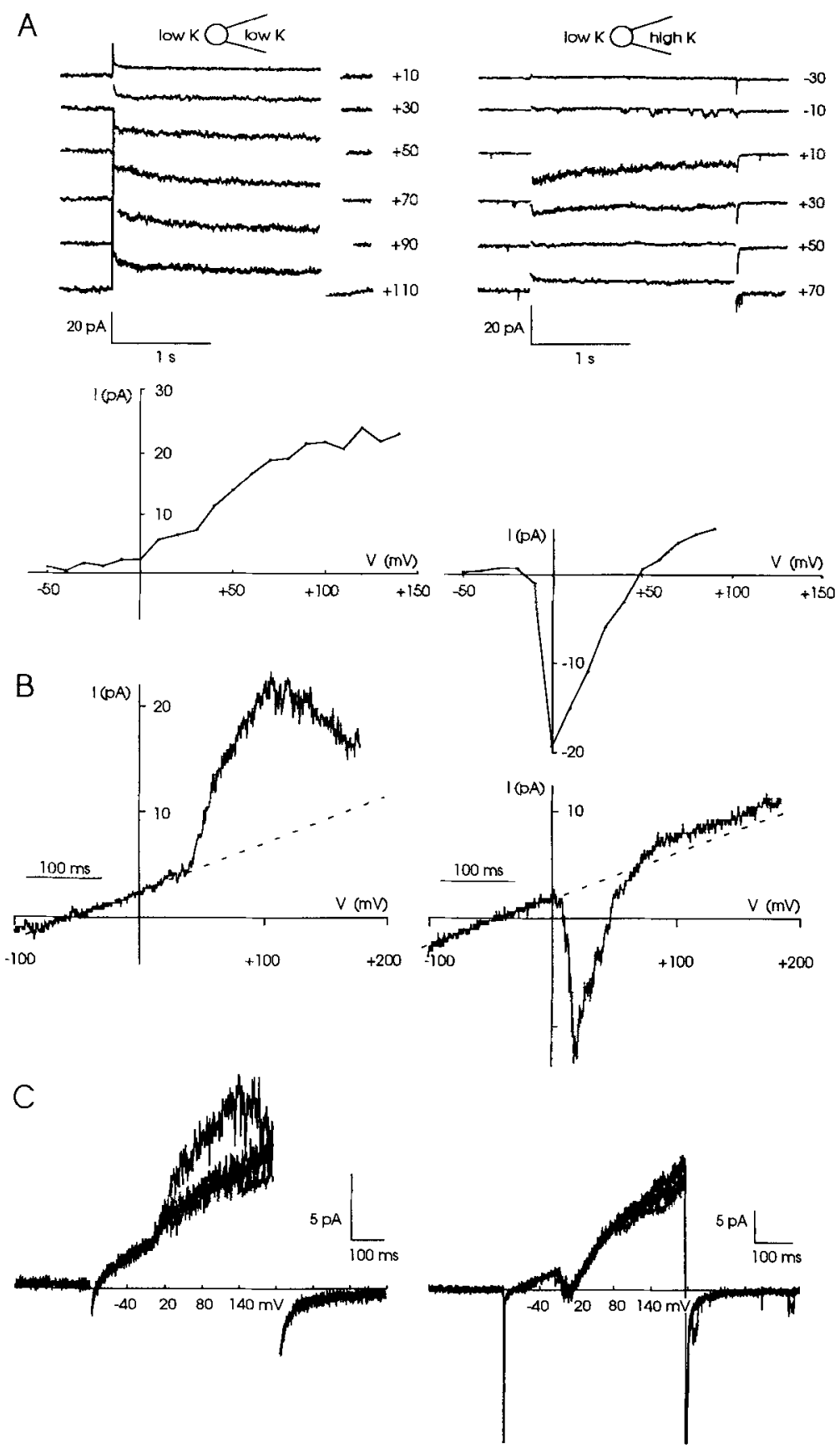

Figure 2. 
interval between consecutive stimulations was sufficient for complete recovery from any current inactivation. When the pipette contained low $\mathrm{K}^{+}$solution, ramp stimulation evoked outward current over the entire range beyond the threshold of $+25 \pm 12$ $\mathrm{mV}(n=7)$; the peak amplitude ranged between 2 and 20 pA (Fig. $2 B$ ). With high $\mathrm{K}^{+}$in the pipette (Fig. $2 B$ ), the current evoked by ramp stimulation was initially inward at potentials beyond a threshold of $+14 \pm 13 \mathrm{mV}(n=27)$. After reaching a peak of 2-35 pA the current declined and reversed direction at potentials in the range from +35 to $+72 \mathrm{mV}(+59 \pm 10 \mathrm{mV} ; n=27)$. This wide range of reversal potentials indicates resting membrane potentials for activated $T$ lymphocytes between -35 and $-72 \mathrm{mV}$.

With low $\mathrm{K}^{+}$pipette solution, the current amplitude gradually decreased at high potentials, consistent with inactivation of the voltage-gated current by prolonged depolarization (Fig. $2 B$, left). With high $\mathrm{K}^{+}$, the marked decrease in the slope of the current beyond the reversal potential (Fig. $2 \mathrm{~B}$, right) is also partially due to inward rectification of the open channels, because inward rectification is also observed in peak $I-V$ relations (see Fig. $2 A$, right). With low $\mathrm{K}^{+}$solution in the pipette, shortening the interval between ramp stimuli to $5 \mathrm{~s}$ inhibits the $\mathrm{K}(V)$ current in successive responses. With high $\mathrm{K}^{+}$, no changes in successive responses are observed for intervals as short as $5 \mathrm{~s}$ (Fig. $2 \mathrm{C}$ ).

The effect of $V_{\mathrm{h}}$ on steady state inactivation was also investigated. The voltage dependence of steady state inactivation was determined by holding the cell-attached patch at various potentials for at least $2 \mathrm{~min}$ before evoking voltage-gated current. Nearly complete inactivation of the $\mathrm{K}(V)$ current was obtained with low $\mathrm{K}^{+}$in the pipette at a $V_{\mathrm{h}}$ of $+60 \mathrm{mV}$, but inactivation was incomplete with high $\mathrm{K}^{+}$at a $V_{\mathrm{h}}$ up to $+100 \mathrm{mV}$ (data not shown). At the resting $V_{\mathrm{m}}\left(V_{\mathrm{h}}=0 \mathrm{mV}\right)$ the average current amplitude was $76 \pm 21 \%(n=3)$ of the value obtained at $V_{\mathrm{h}}=-60 \mathrm{mV}$ with high $\mathrm{K}^{+}$ and $49 \pm 37 \%(n=3)$ with low $\mathrm{K}^{+}$. The degree of inactivation at resting $V_{\mathrm{m}}$ is not significantly different in either situation $(P=0.33)$. The results show that the kinetics of inactivation (Fig. $2 A$ ) as well as the use dependence and steady state voltage dependence of inactivation differ depending on the $\mathrm{K}^{+}$concentration of the pipette

FIGURE 2. (opposite) Cell-attached patch clamp recording of voltage-gated current in patches of activated human $T$ lymphocytes. $(A)$ Currents evoked by depolarizing voltage steps from a $V_{\mathrm{h}}$ of $-60 \mathrm{mV}$ to the indicated potentials and $I-V$ relations of two cell-attached patches with low $\mathrm{K}^{+}$ $\left(\right.$ left) or high $\mathrm{K}^{+}$solution (right) in the pipette. The peak amplitudes of the currents, shown in the upper panels, are plotted vs the applied potential. Single-channel openings can be seen at $-10 \mathrm{mV}$, i.e., near the threshold of activation, with high $\mathrm{K}^{+}$pipette solution. The current decay was fitted by a single exponential function and a nonzero steady level. $(B)$ Currents evoked by voltage ramp stimulation (from -100 to $+200 \mathrm{mV}$ at a rate of $0.6 \mathrm{mV} / \mathrm{ms}$ ) with low $\mathrm{K}^{+}$(left) or high $\mathrm{K}^{+}$solution (right) in the pipette. $V_{\mathrm{h}}$ was $-60 \mathrm{mV}$. A line is drawn through the slope of the current that can be attributed to linear leak current. All determinations of reversal potentials, thresholds and amplitudes of the $\mathrm{K}(V)$ current were corrected for this leak. $(C)$ Use-dependent inactivation of the $\mathrm{K}(V)$ current in cell-attached patches. Four consecutive responses to ramp stimulations at intervals of $5 \mathrm{~s}$ with either low $\mathrm{K}^{+}$solution $(l e f t)$ or high $\mathrm{K}^{+}$solution in the pipette (right). $V_{\mathrm{h}}$ in between ramps was $-60 \mathrm{mV}$. Whereas the amplitude of the $\mathrm{K}(V)$ component decreases with repeated stimulation when the pipette contained low $\mathrm{K}^{+}$solution, a stable response was obtained with high $\mathrm{K}^{+}$solution in the pipette. 
solution. All forms of inactivation were more pronounced with low $\mathrm{K}^{+}$, but it is important to note that at the resting $V_{\mathrm{m}}$ steady state inactivation was incomplete in both low and high $\mathrm{K}^{+}$.

In $\sim 30 \%$ of the experiments with high $\mathrm{K}^{+}$solution in the pipette, the inward current evoked by ramp stimulation consisted of two distinct components, each with a slightly different voltage dependence. The contribution of each component varied between consecutive responses in an apparently random manner (Fig. $3 \mathrm{~A}$, upper traces). When the bath solution was changed to high $\mathrm{K}^{+}$solution, which depolarizes $V_{\mathrm{m}}$, the two-component character disappeared (Fig. $3 \mathrm{~A}$, superimposed traces) then reappeared upon return to low $\mathrm{K}^{+}$(Fig. $3 A$, lower trace). The appearance of the two components was partially inhibited when $V_{\mathrm{h}}$ was changed to more depolarized potentials (data not shown). This suggests that the two components differ in their voltage dependence of inactivation. It is also possible that the component that disappears under depolarized conditions represents channels with fast inactivation kinetics or slow recovery from inactivation. However, shortening the intervals between the ramp depolarizations to $5 \mathrm{~s}$ did not lead to inhibition of either current component (data not shown). The reason for the considerable variability in successive responses of the same cell is unclear. In some cases, apparently distinct components could be attributed to stochastic variation of $\mathrm{K}(V)$-channel opening near the threshold for activation (Fig. $3 B$ ). When the individual currents are superimposed (Fig. $3 \mathrm{~B}$, bottom), discrete opening levels can be distinguished, reflecting the currents through individual channels present in the patch.

\section{Single-Channel Conductance of the $K(V)$ Channel}

High $\mathrm{K}^{+}$pipette solution. In most cells with high $\mathrm{K}^{+}$solution in the pipette, single-channel activity was seen in response to a depolarizing step to $-10 \mathrm{mV}$ from a $V_{\mathrm{h}}$ of $-60 \mathrm{mV}$. In the example shown in Fig. $2 \mathrm{~A}$, the single-channel amplitude at $-10 \mathrm{mV}$ was $2.0 \mathrm{pA}$, with a reversal potential of $+50 \mathrm{mV}$, obtained from the $I-V$ curve of the same patch. From the driving force for $\mathrm{K}^{+}$the single-channel conductance is $\sim 33 \mathrm{pS}$.

The I-V relation of single-channel current could be established in patches that contained a small number of channels. The amplitude of the single-channel open events was determined in response to depolarizing voltage steps to different potentials near the threshold for activation, as illustrated in Fig. 4. The slopes of straight lines drawn through single-channel amplitudes obtained at two or more potentials yielded a single-channel conductance of $33 \pm 15 \mathrm{pS}(n=6)$. The high standard deviation is a consequence of the limited potential range in which discrete single-channel events can be observed. A more reliable estimate of the single-channel conductance is obtained by using the brief single-channel activity in the tail current that follows ramp stimulation, originating from $\mathrm{K}(V)$ channels activated during the ramp. The single-channel conductance of $33.8 \pm 5.0 \mathrm{pS}(n=15)$ is calculated from the amplitude of single-channel events in the tail current (at $V_{\mathrm{h}}=-60 \mathrm{mV}$ ) and the $\mathrm{K}^{+}$current reversal potential from the same record (Fig. $5 \mathrm{~A}$ ).

An extensive analysis of single-channel kinetics was not attempted. Where feasible, the mean open time was determined by dividing the total open time by the total 


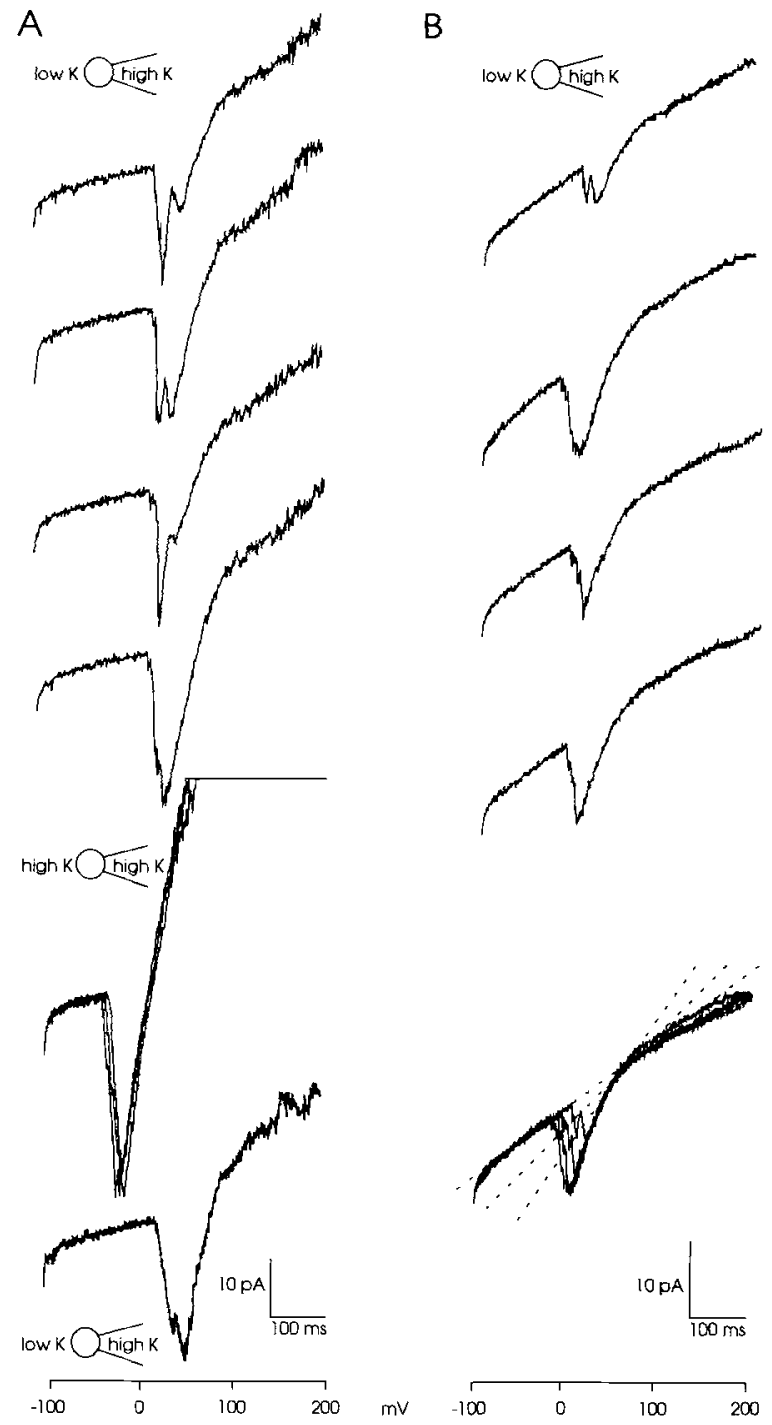

Figure 3. Consecutive responses to ramp stimulation applied at 20 -s intervals in two different patches. The pipette contained high $\mathrm{K}^{+}$solution; $V_{\mathrm{h}}$ in between ramps was $-60 \mathrm{mV}$. (A) Two distinct voltage-gated components can be observed in this patch. The contribution of each component to the total current did not show a systematic pattern (upper traces). The threshold for activation was $27-$ 21-21-18 mV, successively, whereas the reversal potential was $72 \mathrm{mV}$ for all four traces. After superfusion of the cell for 2 min with high $\mathrm{K}^{+}$solution, only one component could be distinguished (superimposed traces). The reversal potential of the current shifted to $+4 \mathrm{mV}$ under this condition. Note the increase in outward current in high $\mathrm{K}^{+}$solution, which saturated the amplifier at the more positive potentials. The effect of high $\mathrm{K}^{+}$solution in the bath was reversible (bottom trace, recorded 2 min after returning to low $\mathrm{K}^{+}$in the bath). (B) A different patch in which apparently distinct components can be distinguished. Superimposing four consecutive traces from this patch reveals distinct open levels, which shows that the apparent occurrence of two

components in this patch can be attributed to variability of channel opening near the threshold. The threshold for activation varied between -17 and $+6 \mathrm{mV}$, whereas the reversal potential was $+55 \mathrm{mV}$ in all four traces.

number of closing transitions. With high $\mathrm{K}^{+}$solution, the mean open time was $222 \pm$ $70 \mathrm{~ms}$ at potentials from -20 to $0 \mathrm{mV}(n=6$; see Fig. 4).

Low $\mathrm{K}^{+}$pipette solution. The single-channel conductance of the $\mathrm{K}(V)$ channel with low $\left[\mathrm{K}^{+}\right]$was determined in patches containing only a few channels, as illustrated in Fig. $5 B$. In the voltage-gated current during ramp stimulation distinct open levels can be discerned, which represent the current through single $\mathrm{K}^{+}$channels. The slopes of these open levels, corrected for leak, yield a mean value of $10.1 \pm 0.8 \mathrm{pS}$ $(n=6)$. 


\section{Using K(V) Current to Measure Membrane Potential}

The reversal potential of the $\mathrm{K}(V)$ current component can be used to monitor $V_{\mathrm{m}}$ (Fig. 6). When the bath solution is changed to high $\mathrm{K}^{+}$, the 1 - $V$ relation shifts to more negative potentials (Fig. 6A). The reversal potential shifts from 59 to $1 \mathrm{mV}$, suggesting a shift of $V_{\mathrm{m}}$ from -59 to $-1 \mathrm{mV}$ in high extracellular $\mathrm{K}^{+}$. The shift in voltage dependence was completely reversible upon returning to low $\mathrm{K}^{+}$bath

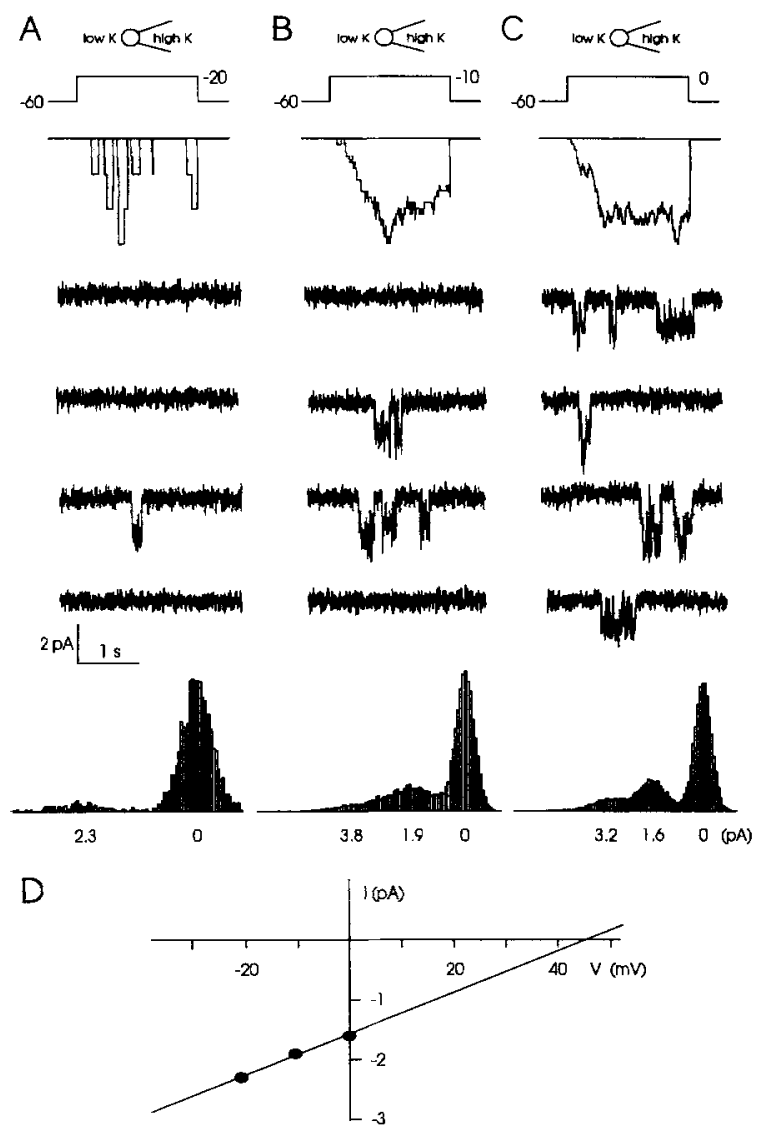

Figure 4. Single-channel analysis of $\mathrm{K}(V)$ channels in cell-attached patches. $(A-C)$ Current traces in response to voltage steps from $V_{\mathrm{h}}=-60$ $\mathrm{mV}$ to the indicated potentials. No channel activity was observed by stepping to $-30 \mathrm{mV}$, whereas stepping to $>0 \mathrm{mV}$ activated compound responses in which no discrete single channels could be distinguished. Four consecutive individual traces, together with the total currents of 50 traces at each potential are shown. Leakage and capacitive currents were eliminated by subtracting averaged records without channel openings. The ensemble current was constructed from idealized current traces that were obtained by fitting the original traces with the mean single-channel open and closed level at each potential. The single-channel open and closed level were determined based on the peaks in the amplitude histograms. The best linear fit of the single-channel amplitude vs potential yields a slope of $35 \mathrm{pS}(D)$. The mean open time of the $\mathrm{K}(V)$ channel was $241 \mathrm{~ms}$ at $-20 \mathrm{mV}$ (26 events), $225 \mathrm{~ms}$ at $-10 \mathrm{mV}$ (45 events) and $207 \mathrm{~ms}$ at $0 \mathrm{mV}$ (161 events).

solution. In only $50 \%$ of the cells bathed in high $\mathrm{K}^{+}$did $V_{\mathrm{m}}$ approach $0 \mathrm{mV}(-1 \pm 4$ $\mathrm{mV} ; n=4)$. In the remainder, $V_{\mathrm{m}}$ depolarized to $-19 \pm 5 \mathrm{mV}(n=4)$.

When $1 \mu \mathrm{M}$ ionomycin is added to the bath, $\mathrm{K}(\mathrm{Ca})$ channels are activated by elevated $\left[\mathrm{Ca}^{2+}\right]_{i}$. In the $I-V$ relations obtained by voltage ramps, the reversal potential and activation threshold of the $\mathrm{K}(V)$ current shift to more positive potentials (Fig. $6 B)$. The reversal potential shift from $67 \pm 8$ to $89 \pm 1 \mathrm{mV}(n=4)$ suggests a 

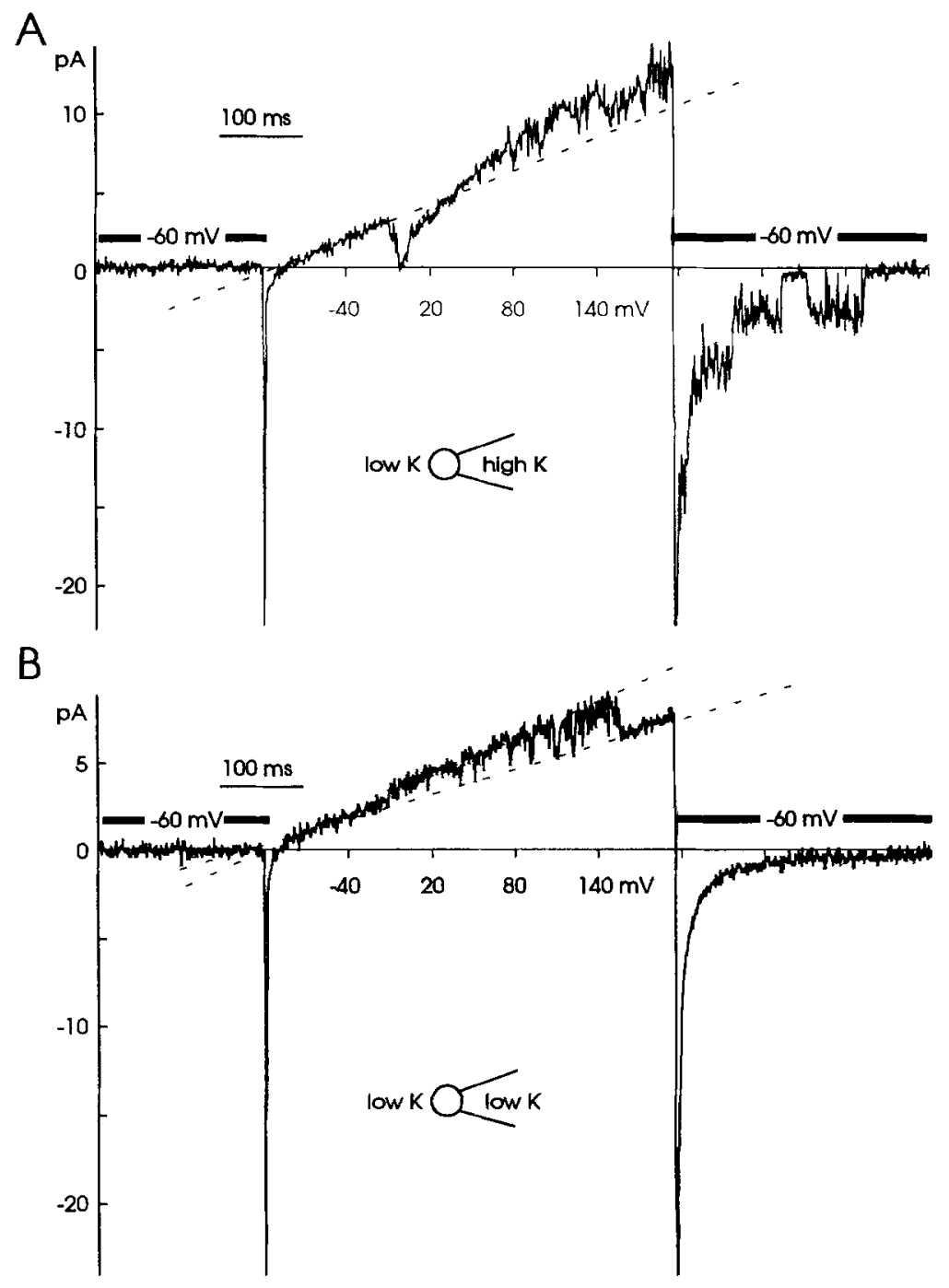

FIGURE 5. Single-channel conductance of the $\mathrm{K}(V)$ channel. $(A)$ High $\mathrm{K}^{+}$solution in the pipette: the voltage-gated channels activated during the ramp give rise to brief single-channel activity after the ramp stimulation when $V_{\mathrm{h}}$ is back to $-60 \mathrm{mV}$. The single-channel conductance of the $\mathrm{K}(V)$ channel can be estimated using single-channel events in the tail. In this record, the single-channel amplitude was $3.43 \mathrm{pA}$. The reversal potential of the voltage-gated current during the ramp was $40 \mathrm{mV}$ (indicating a $V_{\mathrm{m}}$ of $-40 \mathrm{mV}$ of this cell). Hence, the driving force at a $V_{\mathrm{h}}$ of $-60 \mathrm{mV}$ is $-100 \mathrm{mV}$. This yields a single-channel conductance of $34.3 \mathrm{pS}$. $(B)$ Low $\mathrm{K}^{+}$ solution in the pipette: $I-V$ relation of a patch with only one open level. The difference between the open level and the linear leak (dotted lines) yields a single-channel slope conductance of $10 \mathrm{pS}$. 

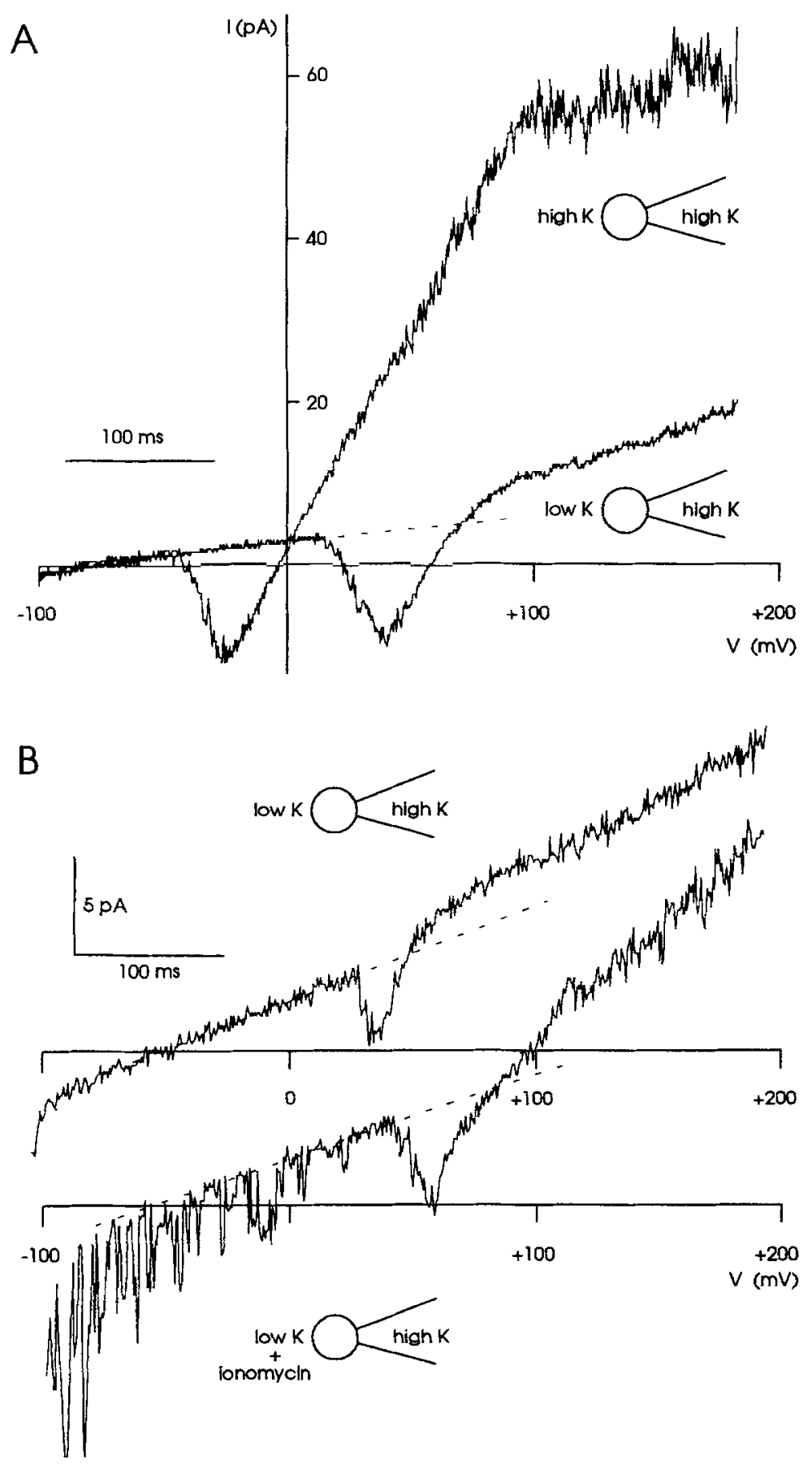

Figure 6. 
hyperpolarization of $V_{\mathrm{m}}$ from -67 to $-89 \mathrm{mV}$, which equals the calculated Nernst potential for $\mathrm{K}^{+}$with $4.5 \mathrm{mM} \mathrm{K}$ in the bath and an estimated $\left[\mathrm{K}^{+}\right]_{\mathrm{i}}$ of $150-160 \mathrm{mM}$. This is consistent with increased membrane $\mathrm{K}^{+}$conductance. The $\mathrm{K}(V)$ component was partially inhibited during stimulation with ionomycin in one out of five cells.

The use of the reversal potential of the voltage-gated current as a quantitative measure for $V_{\mathrm{m}}$ was validated by recording $\mathrm{K}(V)$ currents during a spontaneous burst of $\mathrm{K}(\mathrm{Ca}$ )-channel activity shortly after gigaseal formation (Fig. $7 \mathrm{~A}$ ). $\mathrm{K}(\mathrm{Ca}$ )-channel activity was monitored during a 500 -ms period at $V_{\mathrm{h}}=-60 \mathrm{mV}$ before stimulating the cell-attached patch with the ramp protocol for activating the $\mathrm{K}(V)$ channels. The single $\mathrm{K}(\mathrm{Ca})$-channel conductance can be estimated from the slope of the current, after correction for leakage (Fig. $7 \mathrm{~A}$, dotted lines); the $32.4 \mathrm{pS}$ value is independent of the absolute membrane potential. A 125.6- $\mathrm{mV}$ driving force for $\mathrm{K}^{+}$ions is obtained by dividing the amplitude of the single $\mathrm{K}(\mathrm{Ca})$-channel openings at $V_{\mathrm{h}}(4.07 \mathrm{pA})$, by the single $\mathrm{K}(\mathrm{Ca})$-channel conductance. Since $V_{\mathrm{h}}$ is $-60 \mathrm{mV}, V_{\mathrm{m}}$ is $-65.6 \mathrm{mV}$, virtually identical to the estimate of $-64 \mathrm{mV}$ based on the $\mathrm{K}(V)$-current reversal potential measured from the $I-V$ relation. In Fig. $7 \mathrm{~B}$, the time course of the reversal potential and threshold potential of the $\mathrm{K}(V)$ current are shown, together with $\mathrm{K}(\mathrm{Ca})$ channel activity. The figure illustrates membrane hyperpolarization during the period of $\mathrm{K}(\mathrm{Ca})$-channel activation and $V_{\mathrm{m}}$ fluctuation in the absence of stimulation.

\section{$K(\mathrm{Ca})$ Channels in Cell-attached Patches of PHA-activated Human T Lymphocytes}

$\mathrm{K}(\mathrm{Ca})$ channel numbers in cell-attached patches showed a clear dependence on the time after activation with PHA, as in whole-cell recordings and excised patches (Grissmer et al., 1993; Verheugen et al., 1994a). K(Ca)-channel activity was sporadic in resting $T$ cells; however almost all cell-attached patches contained $\mathrm{K}(\mathrm{Ca})$ channels in cells incubated for $\geq 1 \mathrm{~d}$ with PHA; after 4-5 d of incubation, patches with $>10$ channels were frequently seen. During this period, $\mathrm{T}$ cells evolved into blast cells, and clumps of cells formed, indicating activation by PHA.

An example of single-channel $\mathrm{K}(\mathrm{Ca})$ currents was shown in Fig. $1 \mathrm{C}$. When the holding potential $V_{\mathrm{h}}$ was $0 \mathrm{mV}$ (i.e., only $V_{\mathrm{m}}$ across the patch), channel openings appeared after ionomycin treatment as discrete inward-current steps with an amplitude of $2.9 \pm 0.6 \mathrm{pA}(n=52)$. Hyperpolarization increased and depolarization decreased the single-channel current amplitude (Fig. $8 \mathrm{~A}$ ). Although inward rectification was observed at $V_{\mathrm{h}}>+30 \mathrm{mV}$, the $I-V$ relation from -100 to $+30 \mathrm{mV}$ was essentially linear (Fig. $8 \mathrm{~B}$ ). The slope conductance based on the linear portion of $I-V$

FIgURE 6. (opposite) Changes in $V_{\mathrm{m}}$ indicated by the reversal of the $\mathrm{K}(V)$ current. $(A)$ Comparison of currents elicited by ramp stimulation of the same cell bathed in low $\mathrm{K}^{+}$solution and in high $\mathrm{K}^{+}$solution. In this cell, the reversal potential shifted from $+68 \mathrm{mV}$ in low $\mathrm{K}^{+}$to $+2 \mathrm{mV}$ in high $\mathrm{K}^{+}$solution. In addition to the shift in voltage dependence, a dramatic increase in outward current is observed. The shift in voltage dependence and increase of the outward current were completely reversible (not shown). (B) Currents before application and in the presence of $1 \mu \mathrm{M}$ ionomycin. In addition to induction of $\mathrm{K}(\mathrm{Ca})$ activity (seen at negative potentials) caused by the ionomycin-induced elevation of $\left[\mathrm{Ca}^{2+}\right]_{i}$, the reversal potential of the voltage-gated component shifted from +54 to $+90 \mathrm{mV}$, indicating a hyperpolarization of $V_{\mathrm{m}}$ from -54 to $-90 \mathrm{mV}$. The effects of ionomycin were reversible (not shown). 

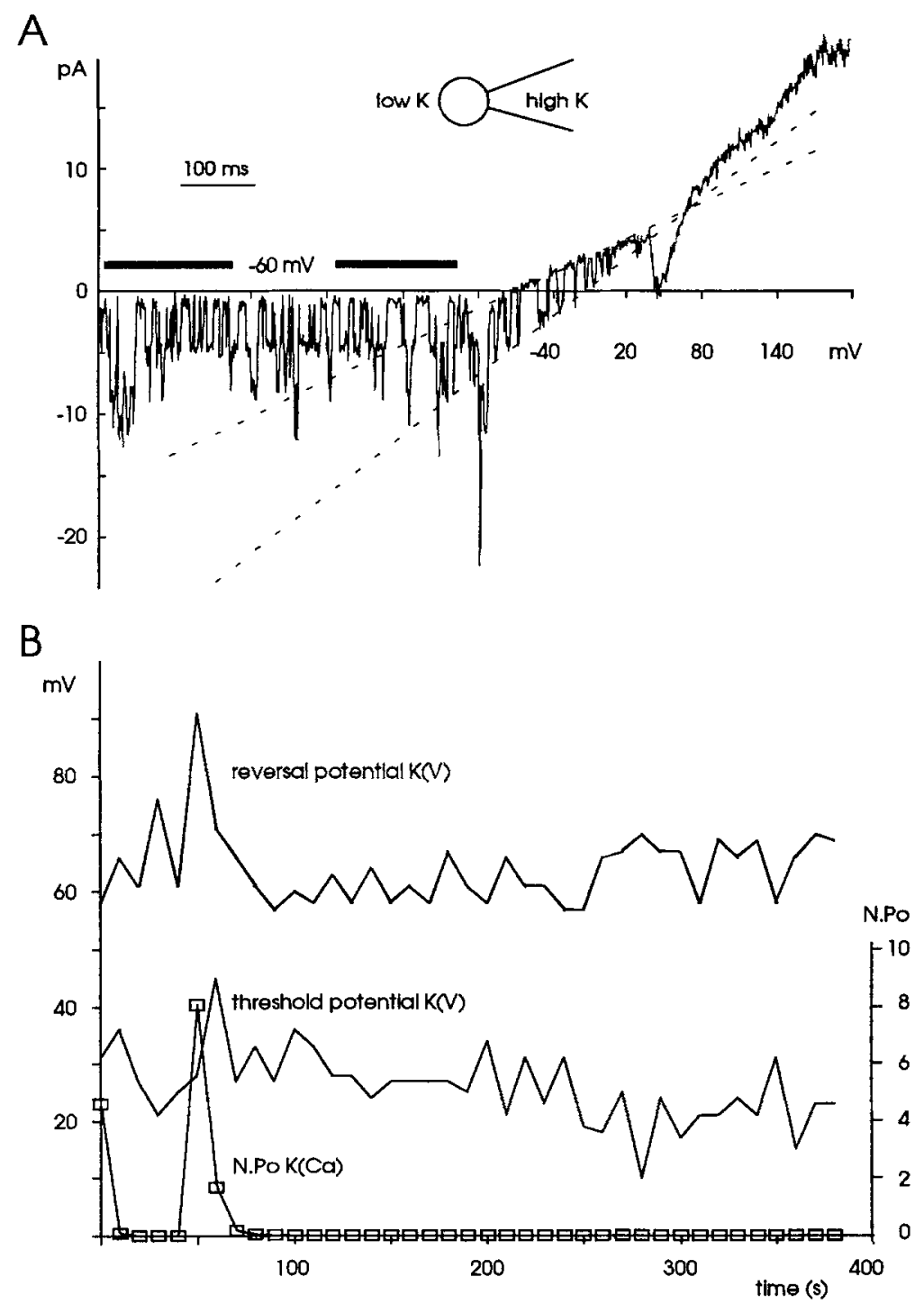

FIGURE 7. (A) Response to ramp stimulation during a spontaneous burst of $\mathrm{K}(\mathrm{Ca})$ activity. Both $\mathrm{K}(\mathrm{Ca})$ and $\mathrm{K}(V)$ channels are present in the patch. The conductance of $\mathrm{K}(\mathrm{Ca})$ channels can be estimated from the difference in slopes of the open and closed level (dotted lines) during the ramp, yielding a conductance of $32.4 \mathrm{pS}$. Using the calculated single-channel conductance and the channel amplitude of the $\mathrm{K}(\mathrm{Ca})$ channel before the ramp stimulation (at a $V_{\mathrm{h}}$ of -60 $\mathrm{mV}$ ) of $4.07 \mathrm{pA}$, the calculated driving force amounts to $125.6 \mathrm{mV}$. $V_{\mathrm{m}}$ estimated from the driving force is $-65.6 \mathrm{mV}$ and the estimate from the $\mathrm{K}(V)$ current reversal potential is $-64 \mathrm{mV}$. $(B)$ The reversal potential and threshold potential of the $\mathrm{K}(\mathrm{V})$ current are plotted together with the activity of $\mathrm{K}(\mathrm{Ca})$ channels in the same patch. A burst of $\mathrm{K}(\mathrm{Ca})$ activity is frequently observed shortly after contact with the patch pipette. Concomitant with the $\mathrm{K}(\mathrm{Ca})$ activity, a shift in the reversal potential occurs, indicating a hyperpolarization of $V_{m}$. In addition, these data illustrate that the $V_{\mathrm{m}}$ is not fixed, but fluctuates within a range of $\sim 10 \mathrm{mV}$ around an average value. 
relationships yielded a single-channel conductance of $36-57 \mathrm{pS}$ (Fig. $8 \mathrm{~B}$ ). The slope conductance of the $\mathrm{K}(\mathrm{Ca})$ channel was also determined from $I-V$ relations obtained by ramp stimulation, after subtraction of a linear leak component (e.g., Figs. $1 D$ and $7 \mathrm{~A}$ ). The slope of the open levels yields a single-channel conductance of $32 \pm 3 \mathrm{pS}$ $(n=3)$. The single-channel conductance seems to be affected by the composition of the pipette solution. With high $\mathrm{K}^{+}$pipette solution, the conductance was $33 \pm 2 \mathrm{pS}$ $(n=4)$; the conductance was $50 \pm 7 \mathrm{pS}(n=3)$ with $\mathrm{Ca}^{2+}$-free high $\mathrm{K}^{+}$(see Fig. 8). The slope conductance appeared constant during bath changes from normal, low $\mathrm{K}^{+}$ to high $\mathrm{K}^{+}$, but the reversal potential (obtained by extrapolation) shifted from 46-90 $\mathrm{mV}(+59 \pm 16 \mathrm{mV} ; n=6)$ in normal bath solution to values close to $0 \mathrm{mV}$ in high $\mathrm{K}^{+}$ solution. Actual reversal of the $\mathrm{K}(\mathrm{Ca})$ current was never observed in cell-attached

A

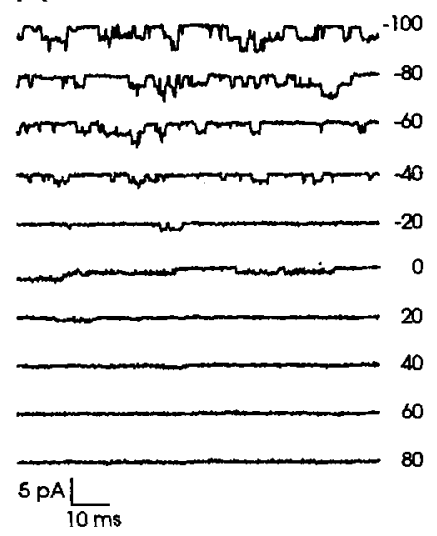

B

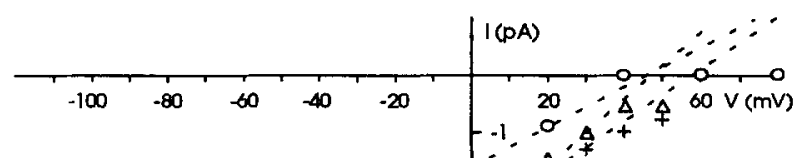

FiGURE 8. (A) Single-channel currents from a cell-attached patch at various holding potentials $\left(V_{\mathrm{h}}\right)$. The pipette contained high $\mathrm{K}^{+}$solution. $(B)$ Current-voltage $(I-V)$ relationship of three different cells. The pipette contained either high $\mathrm{K}^{+}$solution (o) or $\mathrm{Ca}^{2+}$-free high $\mathrm{K}^{+}$solution $(+,-)$. Whereas the channel showed inward rectification at $>30 \mathrm{mV}$, the $I-V$ relation in the potential range of -100 to $30 \mathrm{mV}$ was essentially linear. Fitting the data points in this potential range, using a least-squares algorithm, yielded single-channel conductances and, by extrapolation, reversal potentials of $36 \mathrm{pS}$ and $46 \mathrm{mV}(0), 57 \mathrm{pS}$ and $48 \mathrm{mV}(-), 45 \mathrm{pS}$ and $58 \mathrm{mV}(+)$, respectively.

patches. The fitted reversal potentials are characteristic of $\mathrm{K}^{+}$-selective channels. Furthermore, channel openings were seen when the pipette contained $\mathrm{Ca}^{2+}$-free high $\mathrm{K}^{+}$solution (Fig. $8 \mathrm{~B}$ ), thereby excluding the possibility that the inward current is carried by $\mathrm{Ca}^{2+}$. Because $E_{\mathrm{K}}$ across the patch is $\sim 0 \mathrm{mV}$, reversal potentials at $V_{\mathrm{h}}=46$ to $90 \mathrm{mV}$ indicate that cell membrane potentials are in the range of -46 to $-90 \mathrm{mV}$. The shift towards $0 \mathrm{mV}$ when the bath solution is changed to high $\mathrm{K}^{+}$is consistent with depolarization by high $\left[\mathrm{K}^{+}\right]_{0}$.

\section{K(Ca) Channel Kinetics}

For kinetic analysis, only patches that showed a single open level were used. Due to the large numbers of channels in patches of activated $T$ cells, only two patches 
showed a single open level and were assumed to contain one channel only. The open-time distribution of $\mathrm{K}(\mathrm{Ca})$-channel activity was adequately described by one exponential, with a time constant averaging $2.3 \mathrm{~ms}(n=2)$. The closed-time distribution was fitted with two exponentials having time constants of $0.27 \mathrm{~ms}$ and 8.3 ms $(n=2)$, respectively (Table I). Because the number of exponentials reflects the minimum number of channel states (Horn and Standen, 1983), these data indicate at least one open and two closed states of the $\mathrm{K}(\mathrm{Ca})$ channel in intact human $\mathrm{T}$ lymphocytes.

\section{$\mathrm{Ca}^{2+}$ Sensitivity of $\mathrm{K}(\mathrm{Ca})$ Channels}

Using fura-2, $\left[\mathrm{Ca}^{2+}\right]_{\mathrm{i}}$ of individual cells was measured during patch clamp experiments. After seal formation, $\left[\mathrm{Ca}^{2+}\right]_{\mathrm{i}}$ showed a transient rise in almost every cell. $\left[\mathrm{Ca}^{2+}\right]_{\mathrm{i}}$ increased from a resting level of $30-100 \mathrm{nM}$ to $150-600 \mathrm{nM}$ and returned to

TA B LE 1

Time Constants of the Exponential Functions Fitted to the Open Time and Closed Time Frequency Density Histograms of $\mathrm{K}(\mathrm{Ca})$ Channels in Cell-attached Patches of Human

T Lymphocytes

\begin{tabular}{|c|c|c|c|}
\hline $\begin{array}{c}\text { Cell type } \\
\left(N_{\text {open }} ; N_{\text {closed }}\right)\end{array}$ & $\begin{array}{c}\text { Open time } \\
\tau \\
(P)\end{array}$ & $\frac{\text { Closed time }}{\tau_{1}(\%)}$ & $\tau_{2}(\%)$ \\
\hline $\begin{array}{l}\text { PHA-activated } 5 \text { days } \\
(58 ; 44)\end{array}$ & $\begin{array}{l}2.3 \mathrm{~ms} \\
(0.86)\end{array}$ & $\begin{array}{l}0.39 \mathrm{~ms}(27) \\
(0.64)\end{array}$ & $8.9 \mathrm{~ms}(73)$ \\
\hline $\begin{array}{l}\text { PHA-activated } 5 \text { days } \\
(230 ; 202)\end{array}$ & $\begin{array}{l}2.3 \mathrm{~ms} \\
(0.09)\end{array}$ & $\begin{array}{l}0.15 \mathrm{~ms}(53) \\
(0.54)\end{array}$ & $7.6 \mathrm{~ms}(47)$ \\
\hline
\end{tabular}

Data were obtained from two patches in which only one channel was observed. In both cases, the pipette contained $\mathrm{Ca}^{2+}$-free high $\mathrm{K}^{+}$solution. The $P$ value given between brackets is the result of a $\chi^{2}$ goodness-of-fit test (hypothesis: the observed and fitted histograms have the same distribution). Dual-exponential fitting was performed only when a single-exponential distribution was rejected $(P<0.05)$. The relative contribution of the time constants to dual-exponential fits is indicated between brackets.

resting values within 1-4 min. The time course parallels that of spontaneous channel activity after seal formation (described above). $\left[\mathrm{Ca}^{2+}\right]_{\mathrm{i}}$ could be manipulated by adding 1-5 $\mu \mathrm{M}$ ionomycin to the bath; this procedure elevated $\left[\mathrm{Ca}^{2+}\right]_{\mathrm{i}}$ from $30-100$ $\mathrm{nM}$ to $700-1,000 \mathrm{nM}$; the rise in $\left[\mathrm{Ca}^{2+}\right]_{\mathrm{i}}$ was completed within 2 min. A typical response to ionomycin is shown in Fig. $9 \mathrm{~A}$. A decrease in $\left[\mathrm{Ca}^{2+}\right]_{\mathrm{i}}$ could be induced by changing the bath to high $\mathrm{K}^{+}$solution; this decrease was accelerated by using $\mathrm{Ca}^{2+}$-free high $\mathrm{K}^{+}$solution (Fig. $9 A$ ).

Simultaneous measurements of $\left[\mathrm{Ca}^{2+}\right]_{\mathrm{i}}$ (Fig. $9 \mathrm{~A}$ ) and electrical activity of the patch (Fig. $9 \mathrm{~B}$ ) allowed us to investigate the $\mathrm{Ca}^{2+}$-sensitivity of $\mathrm{K}(\mathrm{Ca})$ channels. To determine the dose-response relation, we used cells in which the ionomycin-induced changes in $\left[\mathrm{Ca}^{2+}\right]_{\mathrm{i}}$ covered a range of several hundred $\mathrm{nM}$. The fractional open time was measured as the total open time, $E$, normalized to the maximal open time, $E_{\max }$. The combined results from four cells are shown in Fig. $9 \mathrm{C}$. Dose-response curves of 

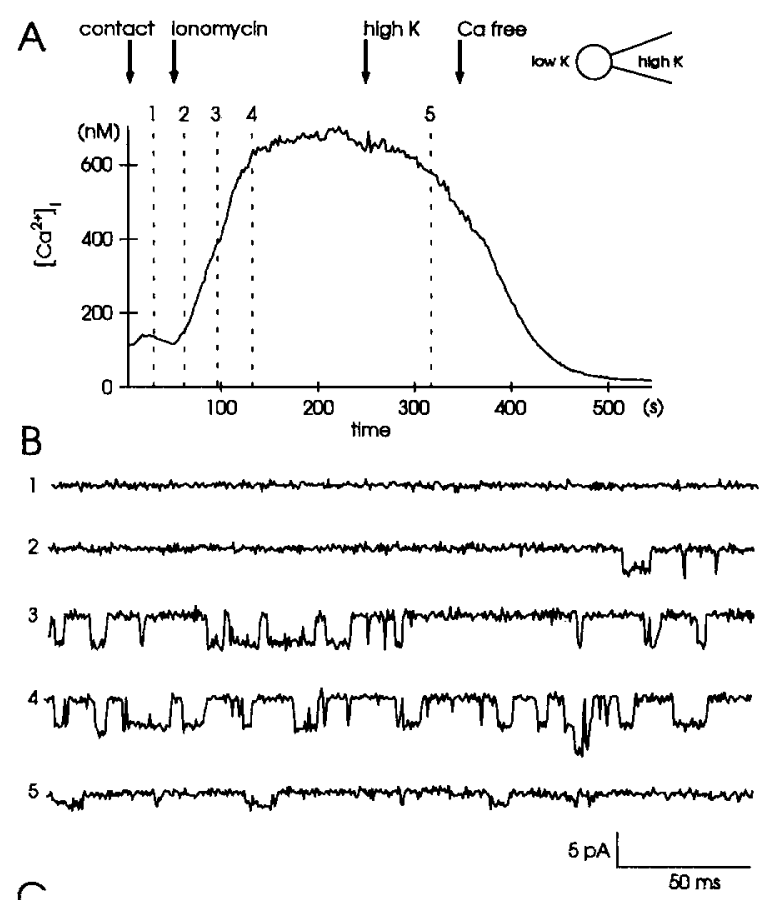

C

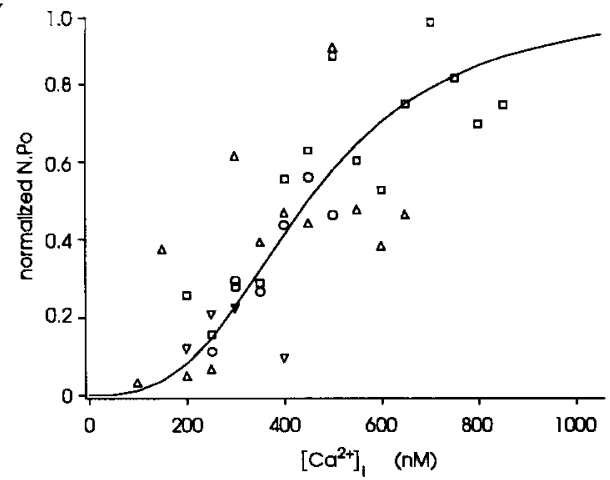

FIGURE 9. Effect of ionomycin on $\left[\mathrm{Ca}^{2+}\right]_{i}(A)$ and on the single-channel activity of a cellattached patch $(B)$ of a PHAactivated T lymphocyte. Channel openings are seen as downward deflections from baseline. Every $2 \mathrm{~s}$, the fura-2 signal was measured and a current trace of $250 \mathrm{~ms}$ was recorded. The $N \cdot P_{\mathrm{o}}$ (see Methods) was then plotted against the corresponding $\left[\mathrm{Ca}^{2+}\right]_{i}$. Note the initial transient rise of $\left[\mathrm{Ca}^{2+}\right]_{i}$ after contact with the patch pipette. The relatively small rise in $\left[\mathrm{Ca}^{2+}\right]_{i}$ did not induce channel activity in this cell. At $t=50 \mathrm{~s}$, the bath solution was changed to a solution containing $5 \mu \mathrm{M}$ ionomycin. At $t=250 \mathrm{~s}$, the bath solution was changed to high $\mathrm{K}^{+}$, and at $t=$ 350 s to $\mathrm{Ca}^{2+}$-free high $\mathrm{K}^{+}$solution. The current traces were recorded at the indicated time points in $\mathrm{A}\left(V_{\mathrm{h}}-60 \mathrm{mV}\right)$. Note the decrease in channel amplitude when the extracellular solution contains high $\mathrm{K}^{+}$(trace 5). (C) Dose-response curve for activation of $\mathrm{K}(\mathrm{Ca})$ channels by $\mathrm{Ca}^{2+}$. Data from four individual cells exposed to $1-5 \mu \mathrm{M}$ ionomycin. The curve is generated by the function $E=1 /(1+$ $\left.\left[450 /\left[\mathrm{Ca}^{2+}\right]\right\}^{3}\right)$. Values for $E C_{50}$ and $n$ of 450 and 3 were determined by fitting each cell individually by eye and then averaging. $E_{\max }$ was normalized to a value of 1 .

individual cells are described by the function:

$$
E=E_{\max } /\left(1+\left\{E C_{50} /\left[\mathrm{Ca}^{2+}\right]\right\}^{\mathrm{n}}\right)
$$

with an $E C_{50}$ at which $E$ is half-maximal of $450 \mathrm{nM}$ and a slope factor, $n$, of $\left.3 . \mathrm{Ca}^{2+}\right]_{\mathrm{i}}$ in cells exposed to $1-5 \mu \mathrm{M}$ ionomycin did not reach values high enough to determine at which $\left[\mathrm{Ca}^{2+}\right]_{\mathrm{i}}$ maximum channel activity occurred. A higher $\left[\mathrm{Ca}^{2+}\right]_{\mathrm{i}}$ (1,000-1,600 $\mathrm{nM}$ ) was attained when $5 \mu \mathrm{M}$ ionomycin, $4 \mu \mathrm{M}$ thapsigargin (a microsomal ATPase inhibitor) and $10 \mathrm{mM} \mathrm{CaCl}_{2}$ were combined in the bath solution. These experiments show that raising $\left[\mathrm{Ca}^{2+}\right]_{i}$ beyond $1 \mu \mathrm{M}$ inhibits channel activity 
(Fig. 10), suggesting that $\mathrm{K}(\mathrm{Ca})$-channel activity peaks below $1 \mu \mathrm{M}\left[\mathrm{Ca}^{2+}\right]_{\mathrm{i}}$. The holding current of these cell-attached patches was unstable, interfering with the quantification of the $P_{\mathrm{o}}$. Therefore, data from these cells was excluded from the dose-response curve of Fig. $9 \mathrm{C}$.

\section{Effects of Ionomycin on the Membrane Potential}

Figs. $9 B$ and $10 B$ illustrate changes in single-channel amplitude as an indicator of $V_{\mathrm{m}}$. The amplitude is determined by the difference between the patch potential $\left(V_{\mathrm{m}}+V_{\mathrm{h}}\right)$ and the $\mathrm{K}^{+}$equilibrium potential. Because the patch potential depends on

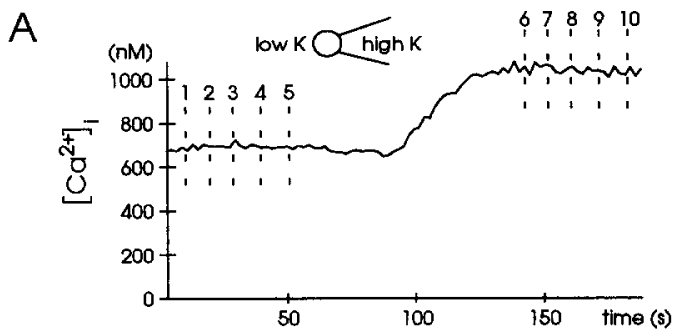

B
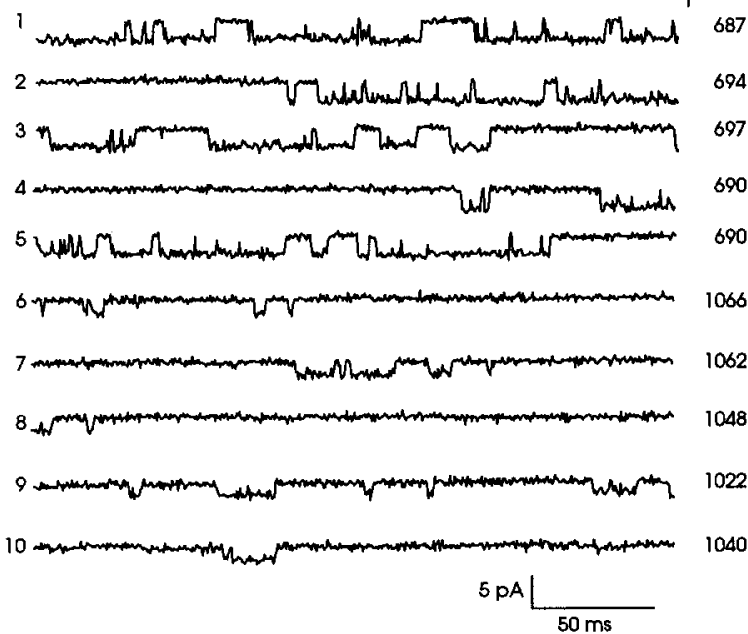

Figure 10. Maximal channel activity occurs at $\left[\mathrm{Ca}^{2+}\right]_{i}<1$ $\mu \mathrm{M}$. In this cell, $\left[\mathrm{Ca}^{2+}\right]_{\mathrm{i}}$ was elevated by the combined application of $5 \mu \mathrm{M}$ ionomycin and $4 \mu \mathrm{M}$ thapsigargin with 10 $\mathrm{mM} \mathrm{CaCl}_{2}$ in the bath solution (at $t=80 \mathrm{~s}$ ). Representative traces were recorded at the indicated time. The decrease in channel activity at higher $\mathrm{Ca}^{2+}$ concentrations is also reflected in the decrease of the current amplitude (see text). $V_{\mathrm{h}}$ was $-60 \mathrm{mV}$.

$V_{\mathrm{m}}$, changes in single-channel amplitude at a constant holding potential reflect changes in $V_{\mathrm{m}}$. The increase in amplitude between trace 2 and trace 4 in Fig. $9 \mathrm{~B}$ (from 3.8 to $4.6 \mathrm{pA}$ at $V_{\mathrm{h}}=-60 \mathrm{mV}$ ) indicates a hyperpolarization due to increased $\mathrm{K}(\mathrm{Ca})$ channel activity resulting from the rise in $\left[\mathrm{Ca}^{2+}\right]_{\mathrm{i}}$. The increased $\mathrm{K}^{+}$conductance causes a shift of $V_{\mathrm{m}}$ from its resting value towards $E_{\mathrm{K}},-89 \mathrm{mV}$ in low $\mathrm{K}^{+}$bath solution. After switching to high $\mathrm{K}^{+}$in the bath (trace 5 in Fig. $9 B$ ), $E_{\mathrm{K}}$ changes to 0 $\mathrm{mV}$ and $V_{\mathrm{m}}$ shift towards this value. The depolarization of $V_{\mathrm{m}}$ is reflected in the decrease of the channel amplitude (to $1.9 \mathrm{pA}$ ). Given that $V_{\mathrm{m}}$ is $0 \mathrm{mV}$ when the cell is in high $\mathrm{K}^{+}$solution, a single-channel conductance of $32 \mathrm{pS}$ can be calculated, 
indicating that $V_{\mathrm{m}}$ changed from $-59 \mathrm{mV}$ (trace 2) to $-84 \mathrm{mV}$ (trace 4) after exposure to ionomycin. By analogy, depolarization due to inhibition of $\mathrm{K}(\mathrm{Ca})$ channel activity at high $\left[\mathrm{Ca}^{2+}\right]_{i}$ is reflected in the decrease of channel amplitude (from 4.0 to 2.8 pA; Fig. $10 B$ ).

\section{Induction of $\mathrm{K}(\mathrm{Ca})$ Channel Activity by Acute Stimulation with PHA}

To assess whether $\mathrm{K}(\mathrm{Ca})$ channels are also activated by stimulating the $\mathrm{T}$-cell receptor/CD3 complex, we applied PHA $(10 \mu \mathrm{g} / \mathrm{ml})$ to the bath and measured $\left[\mathrm{Ca}^{2+}\right]_{\mathrm{i}}$ and single-channel activity of the cell-attached patch (Fig. 11). Within $3 \mathrm{~min}$, $\left[\mathrm{Ca}^{2+}\right]_{\mathrm{i}}$ started to rise (Fig. $11 \mathrm{~A}$ ), $\left[\mathrm{Ca}^{2+}\right]_{\mathrm{i}}$ oscillated moderately, with a peak at 600 $\mathrm{nM}$ after $5.5 \mathrm{~min}$, followed by a gradual decrease towards resting levels: a typical response to PHA in activated T lymphocytes (Hess et al., 1993). Channel openings were concomitant with the rise in $\left[\mathrm{Ca}^{2+}\right]_{\mathrm{i}}$ (representative traces at the indicated time points in Fig. $11 \mathrm{~A}$ are shown in Fig. $11 \mathrm{~B}$ ). In Fig. $11 \mathrm{~A}$, the single-channel amplitude, the $\mathrm{Ca}^{2+}$ signal, and $\mathrm{K}(\mathrm{Ca})$ activity are plotted to show the relation between the three parameters. The close correlation between $\left[\mathrm{Ca}^{2+}\right]_{i}$ and channel amplitude is apparent during the entire period of the $\mathrm{Ca}^{2+}$ signal. The amplitude increase at higher levels of channel activity indicates that opening $\mathrm{K}(\mathrm{Ca})$ channels results in $V_{m}$ hyperpolarization. The correlation between $\left[\mathrm{Ca}^{2+}\right]_{i}$ and $\mathrm{K}(\mathrm{Ca})$ activity is further illustrated in Fig. $11 \mathrm{C}$, in which the open probability of the $\mathrm{K}(\mathrm{Ca})$ channel is plotted against $\left[\mathrm{Ca}^{2+}\right]_{\mathrm{i}}$. The dose-response curve had the same $E C_{50}(450 \mathrm{nM})$ as for ionomycin-treated cells (Fig. $9 \mathrm{C}$ ). The slope, however, appeared somewhat steeper (slope factor, $n$, of 4.5 vs 3 in ionomycin-treated cells).

\section{DIS C USSION}

This paper describes two types of $\mathrm{K}^{+}$channel in intact, activated human $\mathrm{T}$ lymphocytes. A third channel type observed transiently after seal formation was not characterized in detail. Most cell-attached patches contained both voltage-gated $[\mathrm{K}(V)]$ channels and $\mathrm{Ca}^{2+}$-activated $[\mathrm{K}(\mathrm{Ca})]$ channels. The properties of the $\mathrm{K}(V)$ channel (voltage dependence and inactivation kinetics) and the $\mathrm{K}(\mathrm{Ca})$ channel $\left(\mathrm{Ca}^{2+}\right.$ sensitivity) in intact cells indicate that both channels are active under physiological conditions. In addition, from the activity of the $\mathrm{K}(V)$ and $\mathrm{K}(\mathrm{Ca})$ channel in cell-attached patches, the cell membrane potential and the intracellular $\left[\mathrm{Ca}^{2+}\right]$, respectively, can be determined.

\section{$K(V)$ Channels}

Voltage-gated $\mathrm{K}^{+}$channels in cell-attached patches exhibited voltage dependence and inactivation kinetics corresponding to the $n$-type $\mathrm{K}(V)$ current analyzed earlier in whole-cell patch clamp experiments (DeCoursey et al., 1984; Matteson and Deutsch, 1984; Cahalan et al., 1985; DeCoursey et al., 1985; Pahapill and Schlichter, 1990; Verheugen et al., 1994c). The activation threshold of the $\mathrm{K}(V)$ current in cellattached patches was close to the resting membrane potential. On depolarizing voltage steps from a $V_{\mathrm{h}}$ of $-60 \mathrm{mV}, \mathrm{K}(V)$ channels typically activated at $-10 \pm 10 \mathrm{mV}$ relative to $V_{\mathrm{m}}$ (Fig. $2 A$ ). Together with $V_{\mathrm{m}}$ measured in the same cells, the absolute activation threshold is $-52 \pm 8 \mathrm{mV}(n=17)$. The voltage dependence of activation, 


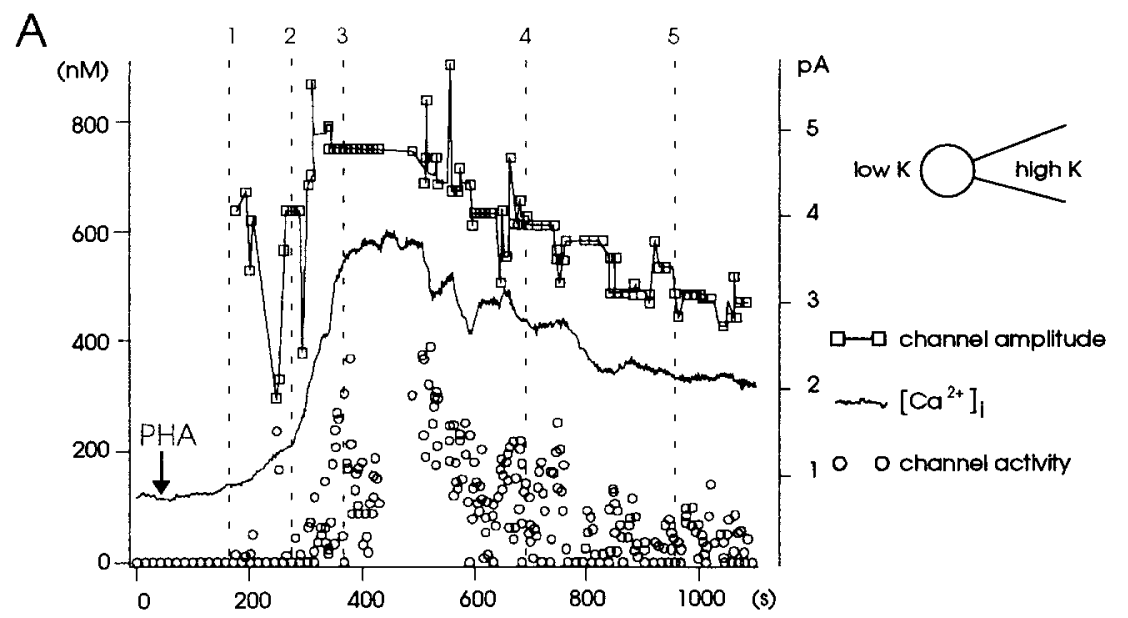

B

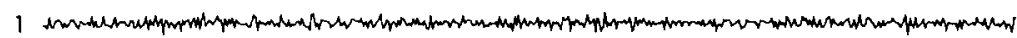

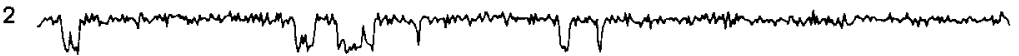

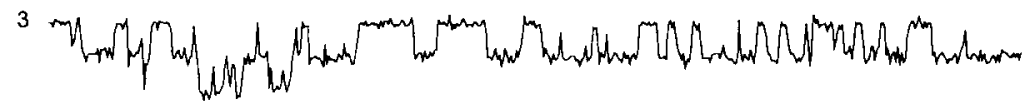

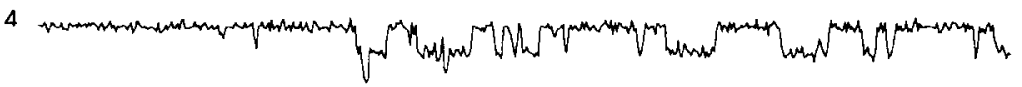

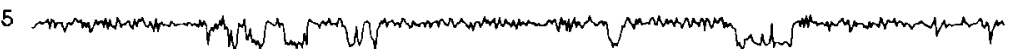
$5 \mathrm{pA}$

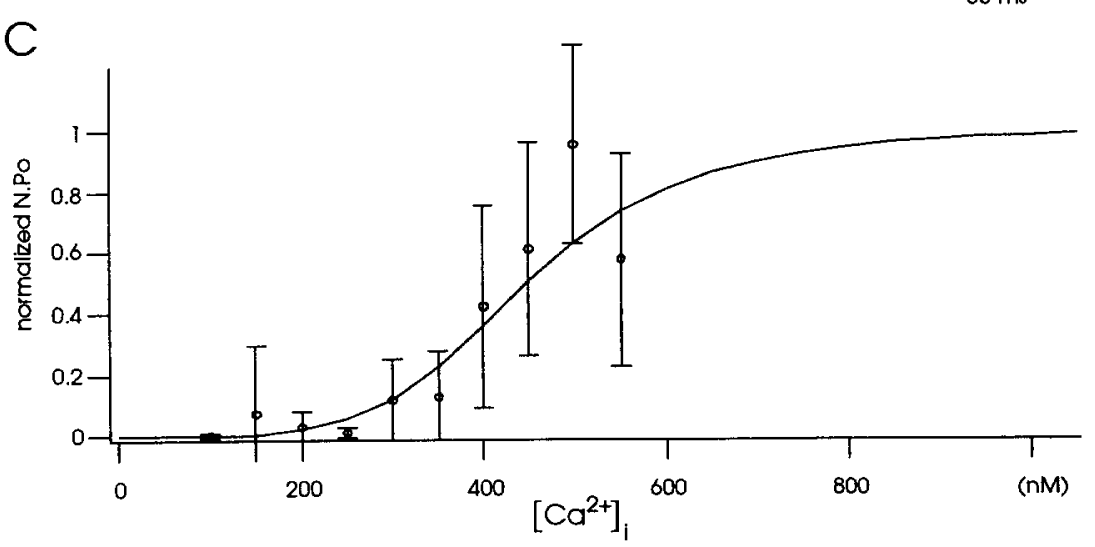

Figure 11. 
along with the observation that inactivation is incomplete near the resting potential, indicate that the $\mathrm{K}(V)$ channel in intact cells is active in the physiological membrane potential range. The time constant of inactivation in cell-attached recordings ( $430 \pm 75 \mathrm{~ms}$ ) was similar to the value of $490 \mathrm{~ms}$ observed in intact resting $T$ cells by Pahapill and Schlichter (1992), but considerably slower than the value of $180 \mathrm{~ms}$ in whole-cell experiments after equilibration (e.g., Cahalan et al., 1985; Verheugen et al., 1994c). During the first minutes after break in to achieve whole-cell recording, inactivation accelerates, suggesting that disruption of the cell alters some intracellular component that modifies channel function (Cahalan et al., 1985). With high $\mathrm{K}^{+}$ pipette solution, the time constant of inactivation in cell-attached patches was $2.5 \mathrm{~s}$ (Fig. $2 A$ ). In whole-cell experiments, a similar slowing of kinetics by high extracellular $\left[\mathrm{K}^{+}\right]$was reported (Cahalan et al., 1985). In addition to its effects on inactivation kinetics, high extracellular $\left[\mathrm{K}^{+}\right]$also reduces use-dependent and steady state inactivation (Fig. $2 C$ ).

Elevation of intracellular $\mathrm{Ca}^{2+}$ has been reported to inhibit $\mathrm{K}(V)$ channels in whole-cell and cell-attached experiments on resting $\mathrm{T}$ lymphocytes (Bregestovski, Redkozubov, and Alexeev, 1986; Attali, Honoré, Lesage, Lazdunski, and Barhanin, 1992a; Pahapill and Schlichter, 1992). However, in our experiments on activated $T$ lymphocytes, partial inhibition of the $\mathrm{K}(V)$ current in the presence of ionomycin was apparent in only one out of five cell-attached patches. With fura-2 measurements, we confirmed that under our experimental conditions, $\left[\mathrm{Ca}^{2+}\right]_{\mathrm{i}}$ was elevated to $\sim 1 \mu \mathrm{M}$ by ionomycin.

The single-channel conductance of the $\mathrm{K}(V)$ channel was $10 \mathrm{pS}$ with $4.5 \mathrm{mM} \mathrm{K} \mathrm{K}^{+}$ and $33 \mathrm{pS}$ with $160 \mathrm{mM} \mathrm{K} \mathrm{K}^{+}$in the pipette, similar to values seen previously in cell-attached and excised patches (Cahalan et al., 1985; Lee et al., 1992; Pahapill and Schlichter, 1992). With high $\mathrm{K}^{+}$in the pipette, the channels rectified inwardly during ramp stimuli. (Fig. 2), as reported in previous studies (Cahalan et al., 1985; Pahapill and Schlichter, 1992). Surprisingly, the degree of rectification was lessened in seven out of eight cells by exposing the cell to high $\mathrm{K}^{+}$in the bath (see Figs. $2 A$ and $5 A$ ). This change may represent conversion to a new channel state, perhaps by voltage dependence of phosphorylation as mentioned below. Alternatively, the change in rectification may result from a decrease in membrane resistance with high $\mathrm{K}^{+}$in the bath as inactivation becomes less complete. Some distortion of the $I-V$ relation determined in cell-attached recordings is to be expected in lymphocytes, because

FIGURE 11. (opposite) (A) Activation of the T cell receptor/CD3 complex by PHA (10 $\mu \mathrm{g} / \mathrm{ml})$ led to both an increase in $\left[\mathrm{Ca}^{2+}\right]_{i}$ and opening of $\mathrm{K}(\mathrm{Ca})$ channels. The amplitude of the single-channel current varied during the $\mathrm{Ca}^{2+}$ signaling, reflecting changes in the membrane potential. At the peak of the $\mathrm{Ca}^{2+}$ signal after $t=400 \mathrm{~s}$, a transient burst of spike-like activity in the electrical recordings impeded quantification of $\mathrm{K}(\mathrm{Ca})$ activity. The two downward deflections of the channel amplitude in the initial phase of the response are more likely the result of opening another kind of channel (e.g., the channel shown in Fig. 1 $A$ ) than of brief depolarizations of $V_{\mathrm{m}} \cdot(B)$ Representative traces of electrical activity taken at the times indicated in $A$. $(C)$ The $\mathrm{K}(\mathrm{Ca})$ activity of $A$ is plotted against the corresponding $\left[\mathrm{Ca}^{2+}\right]_{\mathrm{i}}$. Individual traces of $\mathrm{K}(\mathrm{Ca})$ channel activity were grouped with respect to the $\left[\mathrm{Ca}^{2+}\right]_{\mathrm{i}}$ in ranges of $50 \mathrm{nM} \mathrm{\textrm {Ca } ^ { 2 + }}$. Same equation as in Fig. $9 C$, but using a slope factor of 4.5 instead of 3 for a better fit. 
current through the patch can alter the membrane potential if the input resistance is high. Resting lymphocytes have very high input resistance (10-100 G $\Omega$ (Cahalan et al., 1985), and it has been reported that the amplitude of single-channel currents in cell-attached patches of resting lymphocytes often declines exponentially during the open state (Lee et al., 1992). However, in activated cells, we observed this type of single-channel behavior only very rarely $(<10$ out of hundreds of patches), perhaps because the increased expression of $\mathrm{K}^{+}$channels decreases their input resistance, thereby decreasing the effect of single-channel currents on the membrane potential. The two-component behavior of the $\mathbf{K}(V)$ current seen in a minority of patches (Fig. $3 \mathrm{~A}$ ) might also reflect a perturbation of $V_{\mathrm{m}}$ by the inward patch current in these cells. However, at this time we cannot rule out the possibility that the two components may represent two states of the $\mathrm{K}(V)$ channel, possibly resulting from a varying degree of phosphorylation which has been reported to alter channel properties (Attali et al., 1992a; Payet and Dupuis, 1992).

Using the $K(V)$ component as a probe for $V_{m}$. The present results show that an accurate, quantitative measure for the cell membrane potential is obtained from the reversal potential of the $K(V)$ current, evoked by ramp stimulation, in cell-attached patches. A precondition for accurate $V_{\mathrm{m}}$ measurement is that the patch current itself does not affect $V_{\mathrm{m}}$ significantly. Because the patch current is, by definition, zero at the reversal potential, this method should be accurate even if channels in the patch are open. To validate the method, we derived two independent estimates of $V_{\mathrm{m}}$ from the $\mathrm{K}(\mathrm{Ca})$ channel slope conductance during ramp stimuli and the single-channel amplitude of the $\mathrm{K}(\mathrm{Ca})$ channel at $V_{\mathrm{h}}=-60 \mathrm{mV}$. In 10 experiments, these estimates were always within $2 \mathrm{mV}$ of $V_{\mathrm{m}}$ determined from the $\mathrm{K}(V)$ reversal potential (Fig. $7 \mathrm{~A}$ ). One uncertainty of the method lies in the intracellular $\mathrm{K}^{+}$concentration $\left(\left[\mathrm{K}^{+}\right]_{i}\right)$, which is estimated to be $130-150 \mathrm{mM}$ in human $\mathrm{T}$ lymphocytes (Grinstein and Dixon, 1989). Therefore, with a high $\mathrm{K}^{+}$solution in the pipette, the $E_{\mathrm{K}}$ across the patch is $\sim 0 \mathrm{mV}$. With a $\left[\mathrm{K}^{+}\right]_{\mathrm{i}}$ of $130 \mathrm{mM}$ and with $160 \mathrm{mM} \mathrm{K}{ }^{+}$in the pipette, the $V_{\mathrm{m}}$ estimate would systematically deviate by only $5 \mathrm{mV}$. Only profound changes in $\left[\mathrm{K}^{+}\right]_{\mathrm{i}}$ would cause a significant change in the $E_{\mathrm{K}}$ across the patch, i.e., halving $\left[\mathrm{K}^{+}\right]_{\mathrm{i}}$ would result in a $17 \mathrm{mV}$ error. Such large changes in $\left[\mathrm{K}^{+}\right]_{i}$ are unlikely to occur in the course of the present experiments.

The present method for cells in low $\mathrm{K}^{+}$bath solution yielded $V_{\mathrm{m}}$ values for activated human $T$ lymphocytes of $-59 \pm 11 \mathrm{mV}$, with a range of -35 to $-72 \mathrm{mV}$. With the present method, changes in $V_{\mathrm{m}}$ are readily detected, because each single record of membrane current, which can be obtained every $5 \mathrm{~s}$, provides an updated estimate of $V_{\mathrm{m}}$. Applying ramp stimuli over a prolonged period revealed that the membrane potential of human $\mathrm{T}$ lymphocytes is not a fixed parameter, but fluctuates spontaneously within $\sim 10-20-\mathrm{mV}$ range around the average value (Fig. 7). Fluctuations in $V_{\mathrm{m}}$ were absent during ionomycin-induced hyperpolarization, indicating that they are not an artefact of the method but represent an intrinsic mechanism. In an experiment to examine possible changes in $V_{\mathrm{m}}$ in medium containing $10 \%$ serum, we saw no difference in the mean value of $V_{\mathrm{m}}$ or its fluctuations (data not shown), and ionomycin evoked the usual hyperpolarization as indicated by a shift in reversal potential. Previous measurements of $K(V)$-current reversal potential by step depolarizations in the cell-attached configuration indicate that the average membrane 
potential of resting human T lymphocytes is $-51 \mathrm{mV}$ (Pahapill and Schlichter, 1992). Using potential-sensitive dyes, $V_{\mathrm{m}}$ in lymphocytes was estimated to be in the range of -50 to $-70 \mathrm{mV}$ (for review: Grinstein and Dixon, 1989). The advantages of ramp stimulation, instead of potential-sensitive dyes, include the relatively fast time resolution and high accuracy in single cells. In addition, in contrast to intracellular dyes that necessarily disturb some intracellular component, the cell-attached patch method leaves the intracellular environment unaltered.

Experiments with high $\mathrm{K}^{+}$bath solution and with ionomycin demonstrate that $V_{\mathrm{m}}$ hyperpolarizes to $-89 \pm 1 \mathrm{mV}$ when intracellular $\left[\mathrm{Ca}^{2+}\right]$ is raised. This hyperpolarization to the equilibrium potential for $\mathrm{K}^{+}$is mediated by the activation of the $\mathrm{K}(\mathrm{Ca})$ channels, which are also observed in the cell-attached patch (Figs. $5 \mathrm{~B}$ and $6 \mathrm{~A}$ ). More modest changes in $V_{\mathrm{m}}$ were observed during periods of $\mathrm{K}(\mathrm{Ca})$ channel activity, which are often seen shortly after contact with the patch pipette (see Fig. 7 B). The shift in reversal potential upon changing the bath solution to high $\mathrm{K}^{+}$solution indicates membrane depolarization. In $50 \%$ of the cells, $V_{\mathrm{m}}$ depolarized to values close to 0 $\mathrm{mV}$. However, in the other half of the cells, $V_{\mathrm{m}}$ reached values around $-20 \mathrm{mV}$. Because both the $\mathrm{K}(\mathrm{Ca})$ conductance, as a consequence of a decrease of $\left[\mathrm{Ca}^{2+}\right]_{i}$ at depolarized potentials (Hess et al., 1993), and the $\mathrm{K}(V)$ conductance, as a consequence of inactivation at depolarized potentials (Cahalan et al., 1985; present results) are inhibited at depolarized potentials, the $\mathrm{K}^{+}$conductance may become relatively small compared to other conductances involved in setting the $V_{\mathrm{m}}$. A component of $\mathrm{Cl}^{-}$current, with an equilibrium potential estimated to be -10 to $-35 \mathrm{mV}$ in lymphocytes (Grinstein and Dixon, 1989), may well explain the observed deviation from complete depolarization to $0 \mathrm{mV}$. Thus, it may not be valid to assume that $V_{\mathrm{m}}$ is clamped at $0 \mathrm{mV}$ by high extracellular $\mathrm{K}^{+}$.

\section{$K($ Ca $)$ Channels}

The properties and physiological role of $\mathrm{Ca}^{2+}$-activated $\mathrm{K}^{+}(\mathrm{K}[\mathrm{Ca}])$ channels in intact, activated human $\mathrm{T}$ lymphocytes were examined in the cell-attached configuration of the patch clamp technique, in combination with measurements of intracellular $\left[\mathrm{Ca}^{2+}\right]$ using fura-2. The $\mathrm{K}(\mathrm{Ca})$ channel was activated by raising $\left[\mathrm{Ca}^{2+}\right]_{i}$. Conductance, kinetics, and $\mathrm{Ca}^{2+}$ dependence are similar to those of the IK type $\mathrm{K}(\mathrm{Ca})$ channel described in whole-cell and excised patches of human T lymphocytes (Grissmer et al., 1993; Verheugen et al., 1994a).

The single-channel conductance of the $\mathrm{K}(\mathrm{Ca})$ channel was $50 \pm 7 \mathrm{pS}$, with a solution containing $160 \mathrm{mM} \mathrm{K}^{+}$and no added divalent ions on the extracellular side of the patch. This value is identical to the value found in excised patches of human $T$ lymphocytes under this condition $(50 \pm 6 \mathrm{pS}$; Verheugen et al., 1994a). With a high $\mathrm{K}^{+}$pipette solution containing divalents, the $\mathrm{K}(\mathrm{Ca})$ conductance in cell-attached patches was $33 \pm 2 \mathrm{pS}$, which compares to a conductance of $35 \mathrm{pS}$, reported by Grissmer et al. (1993) for $\mathrm{K}(\mathrm{Ca})$ channels in excised patches of human $\mathrm{T}$ lymphocytes, using a similar extracellular solution. In the human leukemic $\mathrm{T}$ cell line, Jurkat, a 40-60 pS K(Ca) channel was present in small numbers (<10/cell; Grissmer et al., 1992). In cell-attached patches of rat thymocytes and human $B$ lymphocytes, $\mathrm{Ca}^{2+}$-activated $\mathrm{K}^{+}$channels with conductances of $\sim 25 \mathrm{pS}$ were observed under symmetrical high $\mathrm{K}^{+}$conditions. Excised patches from these cells had increased 
single-channel conductances of $\sim 35 \mathrm{pS}$ (Mahaut-Smith and Schlichter, 1989; Mahaut-Smith and Mason, 1991; Partiseti et al., 1992). Lymphocyte K(Ca) channels were sensitive to CTX (Grissmer et al., 1992; Partiseti et al., 1992; Verheugen et al., 1994a). Taking into account the slight differences in experimental conditions, it is likely that the various lymphoid cells express a similar IK channel. Jurkat $\mathrm{T}$ cells appear anomalous in their abundant expression of apamin-sensitive $\mathrm{K}(\mathrm{Ca})$ channels (Grissmer et al., 1992).

Spontaneous activity of two distinct types of channels was observed in $\sim 50 \%$ of the cell-attached patches shortly after gigaseal formation (Fig. 1). At a holding potential of $0 \mathrm{mV}$, a small channel with an amplitude of $1.5 \mathrm{pA}$ was active in most patches for 1-2 min, after which channel activity ceased in about half of the patches. In the remaining patches, a larger $(3 \mathrm{pA})$ channel, with characteristics of the $1 \mathrm{~K}$ type $\mathrm{K}(\mathrm{Ca})$ channel became active for an additional 1-2 min. Hereafter, few patches showed further spontaneous activity. When $\left[\mathrm{Ca}^{2+}\right]_{\mathrm{i}}$ was measured during seal formation, almost invariably a small transient rise of $\left[\mathrm{Ca}^{2+}\right]_{\mathrm{i}}$ was observed after contact with the patch pipette (e.g., Fig. $9 A, t=0$ to $t=60 \mathrm{~s}$ ). The magnitude of this $\mathrm{Ca}^{2+}$ elevation was highly variable, and may be related to the level of mechanical disturbance by the patch pipette. The spontaneous channel activity can be explained by activation of two distinct channels with different $\mathrm{Ca}^{2+}$-sensitivities. The character of this channel activity depends on whether the spontaneous rise in $\left[\mathrm{Ca}^{2+}\right]_{i}$ reaches the activation threshold for activation of the distinct $\mathrm{Ca}^{2+}$-activated channels. The smaller channel seems to be activated at low $\left[\mathrm{Ca}^{2+}\right]_{\mathrm{i}}$ and inhibited by slightly higher $\left[\mathrm{Ca}^{2+}\right]_{\mathrm{i}}$ : simultaneous activity of both channels occurs only for a limited period of time. In general, once the activity of the smaller channel disappeared it did not reappear, thus pointing to the role of additional factors in determining the state of this channel. Perhaps this is why the channel is virtually always "lost" after patch excision (Verheugen et al., 1994a). A similar loss of a small $\mathrm{Ca}^{2+}$-activated conductance after excision was reported in rat thymocytes (Mahaut-Smith and Schlichter, 1989). It remains to be determined if this smaller channel resembles the 6-8 pS, apaminsensitive $\mathrm{K}(\mathrm{Ca})$ channel, which is the predominant $\mathrm{K}(\mathrm{Ca})$ channel in Jurkat $\mathrm{T}$ cells (Grissmer et al., 1992), or a small CTX-sensitive $\mathrm{K}(\mathrm{Ca})$ channel, observed in resting $\mathrm{T}$ lymphocytes (Leonard et al., 1992). The possibility that this smaller channel represents $\mathrm{K}(V)$ channels opened upon mechanically induced depolarization seems less likely, considering the differences in mean open time of this channel and the $\mathrm{K}(V)$ channel ( 7.4 and $222 \mathrm{~ms}$, respectively).

The present results show that the IK type $\mathrm{K}(\mathrm{Ca})$ channel of $\mathrm{T}$ lymphocytes can be activated by physiological stimuli. Stimulation of the $T$ cell receptor/CD3 complex with PHA results in induction of $\mathrm{K}(\mathrm{Ca})$ channel activity, along with the PHA-induced $\mathrm{Ca}^{2+}$ signal (Fig. 11). In addition, the single-channel amplitude increased in parallel with the $\mathrm{K}(\mathrm{Ca})$ channel activity, indicating a membrane hyperpolarization. Associated with stimulation of the $\mathrm{T}$ cell receptor/CD3 complex, changes in membrane potential have been reported by various authors (reviewed in Grinstein and Dixon, 1989). There is poor agreement, however, concerning the direction and magnitude of these changes. These differences may be attributed to the method used. Oxonol dyes consistently indicated membrane hyperpolarization potential after stimulation with the T-cell mitogens ConA and PHA (Tsien, Pozzan, and Rink, 1982; Felber and 
Brand, 1983; Tatham and Delves, 1984; Tatham, O'Flynn, and Linch, 1986; Mahaut-Smith and Mason, 1991). The present results indicate that the hyperpolarization depends both on $\left[\mathrm{Ca}^{2+}\right]_{i}$ and the presence of $\mathrm{K}(\mathrm{Ca})$ channels.

Hyperpolarization of the membrane potential increases the driving force for $\mathrm{Ca}^{2+}$ influx. Thus, $\mathrm{K}(\mathrm{Ca})$ channels may contribute to positive feedback between $\left[\mathrm{Ca}^{2+}\right]_{i}$ and the membrane potential. Consistent with this possibility, increased expression of $\mathrm{K}(\mathrm{Ca})$ channels correlates with the increased tendency of activated $\mathrm{T}$ cells to exhibit an oscillatory $\mathrm{Ca}^{2+}$ signal in response to $\mathrm{T}$-cell receptor stimulation (Grissmer et al., 1993; Hess et al., 1993). Because physiological $\mathrm{Ca}^{2+}$ signaling is transient or oscillatory in character, the regulatory system that controls the $\left[\mathrm{Ca}^{2+}\right]_{\mathrm{i}}$ must comprise negative feedback as well. Both the $\mathrm{K}(V)$ channel and the $\mathrm{K}(\mathrm{Ca})$ channel are inhibited by high $\left[\mathrm{Ca}^{2+}\right]_{i}$ (Bregestovski et al., 1986; present result). Because this only occurs at concentrations $>1 \mu \mathrm{M}$, a higher level than occurs during most $\mathrm{Ca}^{2+}$ oscillations in human $\mathrm{T}$ lymphocytes (Hess et al., 1993), inhibition of the $\mathrm{K}^{+}$channels by high $\left[\mathrm{Ca}^{2+}\right]_{\mathrm{i}}$ seems unlikely as a negative feedback mechanism. Instead, inhibition of $\mathrm{Ca}^{2+}$ channel activity by high $\left[\mathrm{Ca}^{2+}\right]_{i}$ has been suggested (Lewis and Cahalan, 1989; Donnadieu, Bismuth, and Trautmann, 1992). A mitogen- or $\mathrm{IP}_{3}$-activated $\mathrm{Ca}^{2+}$ conductance that is inactivated by elevation of $\left[\mathrm{Ca}^{2+}\right]_{\mathrm{i}}$, is present in Jurkat $\mathrm{T}$ cells (Kuno and Gardner, 1987; Lewis and Cahalan, 1989; McDonald, Premack, and Gardner, 1993; Zweifach and Lewis, 1993), but the exact nature of the $\mathrm{Ca}^{2+}$ conductance in normal human $T$ lymphocytes remains to be elucidated. In this respect, it is noteworthy that no $\mathrm{Ca}^{2+}$ channel activity was observed in the cellattached patch during the response to PHA.

Our results demonstrate the feasibility of using the cell-attached configuration of the patch-clamp technique to measure physiological changes in membrane potential. The magnitude of the membrane potential is reflected in the reversal potential of the $\mathrm{K}(\mathrm{V})$ current (Fig. 6 ) and, qualitatively, in the amplitude of the single $\mathrm{K}(\mathrm{Ca}$ )-channel current, measured in the cell-attached patch (Fig. 11). Because the $\mathrm{Ca}^{2+}$ dependence of $\mathrm{K}(\mathrm{Ca})$ channels in cell-attached patches of human $\mathrm{T}$ lymphocytes has been described in detail (Fig. 9; Grissmer et al., 1993; Verheugen et al., 1994a), the K(Ca) channel activity may be used to estimate $\left[\mathrm{Ca}^{2+}\right]_{\mathrm{i}}$. Recording both $\mathrm{K}(V)$ and $\mathrm{K}(\mathrm{Ca})$ channel activity in cell-attached patches makes it possible to monitor membrane potential and $\left[\mathrm{Ca}^{2+}\right]_{\mathrm{i}}$ simultaneously under physiological conditions, without disturbing the cytoplasmic environment, e.g., the buffering of $\left[\mathrm{Ca}^{2+}\right]_{i}$ by fura-2. We have applied this approach to study the interaction of membrane potential with $\mathrm{Ca}^{2+}$ and $\mathrm{K}^{+}$channels during signal transduction following T-cell receptor stimulation (Verheugen and Vijverberg, 1995).

We thank Paula Martens, Floor Brons, Inge Mohede, and Luette Forrest for isolating the $\mathrm{T}$ lymphocytes and maintaining the cell cultures. We thank Aart de Groot for electronics and computer support.

This investigation was supported by NIH Grant NS14609 and GM41514 (M. D. Cahalan); by a fellowship from the Royal Netherlands Academy of Arts and Sciences (M. Oortgiesen), and a travel grant from the Netherlands Organization for Scientific Research (J. Verheugen).

Original version received 25 August 1994 and accepted version received 28 February 1995. 


\section{R E F E R E N C E S}

Amigorena, S., D. Choquet, J. L. Teillaud, H. Korn, and W. H. Fridman. 1990. Ion channels blockers inhibit $B$ cell activation at a precise stage of the $G_{1}$ phase of the cell cycle: possible involvement of $\mathrm{K}^{+}$channels. Journal of Immunology. 144:2038-2045.

Attali, B., E. Honoré, F. Lesage, M. Lazdunski, and J. Barhanin. 1992a. Regulation of a major cloned voltage-gated $\mathrm{K}^{+}$channel from human $\mathrm{T}$ lymphocytes. FEBS Letters. 303:229-232.

Attali, B., G. Romey, E. Honoré, A. Schmid-Alliana, M. G. Mattéi, F. Lesage, P. Ricard, J. Barhanin, and M. Lazdunski. 1992b. Cloning, functional expression, and regulation of two $\mathrm{K}^{+}$channels in human T lymphocytes. Journal of Biological Chemistry. 267:8650-8657.

Bregestovski, P., A. Redkozubov, and A. Alexeev. 1986. Elevation of intracellular calcium reduces voltage-dependent potassium conductance in human T cells. Nature. 319:776-778.

Cahalan, M. D., K. G. Chandy, T. E. DeCoursey, and S. Gupta. 1985. A voltage-gated potassium channel in human T lymphocytes. Journal of Physiology. 358:197-237.

Cahalan, M. D., and R. S. Lewis. 1988. Role of potassium and chloride channels in volume regulation by T lymphocytes. In Cell Physiology of Blood. Society of General Physiologists Series. Vol. 43. R. B. Gunn and J. C. Parker, editors. The Rockefeller University Press, NY. 281-301.

Cahalan, M. D., and R. S. Lewis. 1990. Functional roles of ion channels in lymphocytes. Seminars in Immunology. 2:107-117.

Cai, Y. C., and J. Douglass. 1993. In vivo and in vitro phosphorylation of the T lymphocyte type $n$ (Kv 1.3) potassium channel. Journal of Biological Chemistry. 268:23720-23727.

Cai, Y. C., P. B. Osborne, R. A. North, D. C. Dooley, and J. Douglass. 1992. Characterization and functional expression of genomic DNA encoding the human lymphocyte type $n$ potassium channel. DNA and Cell Biology. 11:163-172.

Chandy, K. G., T. E. DeCoursey, M. D. Cahalan, D. McLaughlin, and S. Gupta. 1984. Voltage-gated potassium channels are required for human $\mathrm{T}$ lymphocyte activation. Joumal of Experimental Medicine. 160:369-385.

Chandy, K. G. 1991. Simplified gene nomenclature. Nature. 352:26.

DeCoursey, T. E., K. G. Chandy, S. Gupta, and M. D. Cahalan. 1984. Voltage-gated $\mathrm{K}^{+}$channels in human T-lymphocytes: a role in mitogenesis? Nature. 307:465-468.

DeCoursey, T. E., K. G. Chandy, S. Gupta, and M. D. Cahalan. 1985. Voltage-dependent ion channels in T-lymphocytes. Journal of Neuroimmunology. 10:71-95.

DeCoursey, T. E., K. G. Chandy, S. Gupta, and M. D. Cahalan. 1987. Mitogen induction of ion channels in murine T lymphocytes. Journal of General Physiology. 89:405-420.

Deutsch, C., and L. Q. Chen. 1993. Heterologous expression of specific $\mathrm{K}^{+}$channels in $\mathrm{T}$ lymphocytes: functional consequences for volume regulation. Proceedings of the National Academy of Sciences, USA. 90:10036-10040.

Deutsch, C., D. Krause, and S. C. Lee. 1986. Voltage-gated potassium conductance in human T-lymphocytes stimulated with phorbol ester. Journal of Physiology. 372:405-423.

Diem, K., and C. Lentner. 1971. In Wissenschaftliche Tabellen. Giba-Geigy A.G., Basel, Switzerland. 175-180.

Donnadieu, E., G. Bismuth, and A. Trautmann. 1992. Calcium fluxes in T lymphocytes. Journal of Biological Chemistry. 267:25864-25872.

Dreyer, F. 1990. Peptide toxins and potassium channels. Reviews of Physiology, Biochemistry and Pharmacology. 115:93-136.

Felber, S. B., and M. D. Brand. 1983. Early plasma-membrane-potential changes during stimulation of lymphocytes by concanavalin A. Biochemical Joumal. 210:885-891.

Gallin, E. K. 1991. Ion channels in leukocytes. Physiological Reviews. 71:775-811. 
Gelfand, E. W., R. K. Cheung, and S. Grinstein. 1984. Role of membrane potential in the regulation of lectin-induced calcium uptake. Journal of Cellular Physiology. 121:533-539.

Grinstein, S., and S. J. Dixon. 1989. Ion transport, membrane potential, and cytoplasmic pH in lymphocytes: changes during activation. Physiological Reviews. 69:417-481.

Grinstein, S., and J. D. Smith. 1990. Calcium-independent cell volume regulation in human lymphocytes. Journal of General Physiology. 95:97-120.

Grissmer, S., B. Dethlefs, J. Wasmuth, A. L. Goldin, G. A. Gutman, M. D. Cahalan, and K. G. Chandy. 1990. Expression and chromosomal localization of a lymphocyte $\mathrm{K}^{+}$channel gene. Proceedings of the National Academy of Sciences, USA. 87:9411-9415.

Grissmer, S., R. S. Lewis, and M. D. Cahalan. 1992. $\mathrm{Ca}^{2+}$-activated $\mathrm{K}^{+}$channels in human leukemic T cells. Journal of General Physiology. 99:63-84.

Grissmer, S., A. N. Nguyen, and M. D. Cahalan. 1993. Calcium-activated potassium channels in resting and activated human $\mathrm{T}$ lymphocytes: expression levels, calcium dependence, ion selectivity, and pharmacology. Journal of General Physiology. 102:601-630.

Grynkiewicz, G., M. Poenie, and R. Y. Tsien. 1985. A new generation of $\mathrm{Ca}^{2+}$ indicators with greatly improved fluorescence properties. Journal of Biological Chemistry. 260:3440-3450.

Hamill, O. P., A. Marty, E. Neher, B. Sakmann, and F. J. Sigworth. 1981. Improved patch-clamp techniques for high-resolution current recording from cells and cell-free membrane patches. Pflügers Archiv. 391:85-100.

Hess, S. D., M. Oortgiesen, and M. D. Cahalan. 1993. Calcium oscillations in human T and NK cells depend upon membrane potential and calcium influx. Joumal of Immunology. 150:2620-2633.

Horn, R., and N. B. Standen. 1983. Counting kinetic states: the single channel approach. In The Physiology of Excitable Cells. A. Grinell, and W. Moody, editors. Alan R. Liss, Inc., NY. 181-189.

Kuno, M., and P. Gardner. 1987. Ion channels activated by inositol 1,4,5-trisphosphate in plasma membrane of human T-lymphocytes. Nature. 326:301-304.

Lee, S. C., D. I. Levy, and C. Deutsch. 1992. Diverse $\mathrm{K}^{+}$channels in primary human T lymphocytes. Journal of General Physiology. 99:771-793.

Leonard, R. J., M. L. Garcia, R. S. Slaughter, and J. P. Reuben. 1992. Selective blockers of voltage-gated $\mathrm{K}^{+}$channels depolarize human $\mathrm{T}$ lymphocytes: mechanism of the antiproliferative effect of charybdotoxin. Proceedings of the National Academy of Sciences, USA. 89:10094-10098.

Lewis, R. S., and M. D. Cahalan. 1989. Mitogen-induced oscillations of cytosolic $\mathrm{Ca}^{2+}$ and transmembrane $\mathrm{Ca}^{2+}$ current in human leukemic $\mathrm{T}$ cells. Cell Regulation. 1:99-112.

Lin, C. S., R. C. Boltz, J. T. Blake, M. Nguyen, A. Talento, P. A. Fischer, M. S. Springer, N. H. Sigal, R. S. Slaughter, M. L. Garcia, G. J. Kaczorowski, and G. C. Koo. 1993. Voltage-gated potassium channels regulate calcium-dependent pathways involved in human $\mathrm{T}$ lymphocyte activation. Journal of Experimental Medicine. 177:637-645.

Mahaut-Smith, M. P., and M. J. Mason. 1991. $\mathrm{Ca}^{2+}$-activated $\mathrm{K}^{+}$channels in rat thymic lymphocytes: activation by concanavalin A. Journal of Physiology. 439:513-528.

Mahaut-Smith, M. P., and L. C. Schlichter. 1989. $\mathrm{Ca}^{2+}$-activated $\mathrm{K}^{+}$channels in human B lymphocytes and rat thymocytes. Journal of Physiology. 415:69-83.

Marquardt, D. W. 1963. An algorithm for least-squares estimation of non-linear parameters. Journal of the Society for Industrial and Applied Mathematics. 11:431-441.

Matteson, D. R., and C. Deutsch. 1984. K channels in T-lymphocytes: a patch clamp study using monoclonal antibody adhesion. Nature. 307:468-471.

McDonald, T. V., B. A. Premack, and P. Gardner. 1993. Flash photolysis of caged inositol 1,4,5-trisphosphate activates plasma membrane calcium current in human $\mathrm{T}$ cells. Journal of Biological Chemistry. 268:3889-3896. 
Oettgen, H. C., C. Terhorst, L. C. Cantley, and P. M. Rosoff. 1985. Stimulation of the T3-T cell receptor complex induces a membrane-potential-sensitive calcium influx. Cell. 40:583-590.

Pahapill, P. A., and L. C. Schlichter. 1990. Modulation of potassium channels in human Tlymphocytes: effects of temperature. Journal of Physiology. 422:103-126.

Pahapill, P. A., and L. C. Schlichter. 1992. Modulation of potassium channels in intact human T lymphocytes. Journal of Physiology. 445:407-430.

Partiseti, M., D. Choquet, A. Diu, and H. Korn. 1992. Differential regulation of voltage- and calcium-activated potassium channels in human B lymphocytes. Journal of Immunology. 148:33613368.

Partiseti, M., H. Korn, and D. Choquet. 1993. Pattern of potassium channel expression in proliferating B lymphocytes depends upon the mode of activation. Journal of Immunology. 151:2462-2470.

Payet, M. D., and G. Dupuis. 1992. Dual regulation of the n type $\mathrm{K}^{+}$channel in Jurkat T lymphocytes by protein kinases A and C. Journal of Biological Chemistry. 267:18270-18273.

Sands, S. B., R. S. Lewis, and M. D. Cahalan. 1989. Charybdotoxin blocks voltage-gated $\mathrm{K}^{+}$channels in human and murine T lymphocytes. Journal of General Physiology. 93:1061-1074.

Tatham, P. E. R., and P. J. Delves. 1984. Flow cytometric detection of membrane potential changes in murine lymphocytes induced by concanavalin A. Biochemical Journal. 221:137-146.

Tatham, P. E. R., K. O'Flynn, and D. C. Linch. 1986. The relationship between mitogen-induced membrane potential change and intracellular free calcium in human T-lymphocytes. Biochimica et Biophysica Acta. 856:202-211.

Tsien, R. Y., T. Pozzan, and T. J. Rink. 1982. T-cell mitogens cause early changes in cytoplasmic free $\mathrm{Ca}^{2+}$ and membrane potential in lymphocytes. Nature. 295:68-71.

Verheugen, J. A. H., R. G. D. M. van Kleef, M. Oortgiesen, and H. P. M. Vijverberg. 1994a. Characterization of $\mathrm{Ca}^{2+}$-activated $\mathrm{K}^{+}$channels in excised patches of human $\mathrm{T}$ lymphocytes. Pflügers Archiv. 426:465-471.

Verheugen, J. A. H., M. Oortgiesen, and M. D. Cahalan. 1994b. Simultaneous $\left[\mathrm{Ca}^{2+}\right]_{\mathrm{i}}$ and $\mathrm{K}^{+}$channel measurements in human T lymphocytes. Biophysical Journal. 66:A325. (Abstr.)

Verheugen, J. A. H., M. Oortgiesen, and H. P. M. Vijverberg. 1994c. Veratridine blocks voltage-gated potassium current in human $\mathrm{T}$ lymphocytes and in mouse neuroblastoma cells. Jourmal of Membrane Biology. 137:205-214.

Verheugen, J. A. H., and H. P. M. Vijverberg. 1995. Intracellular $\mathrm{Ca}^{2+}$ oscillations and membrane potential fluctuations in intact human $\mathrm{T}$ lymphocytes: role of $\mathrm{K}^{+}$channels in $\mathrm{Ca}^{2+}$ signaling. Cell Calcium. In press.

Zweifach, A., and R. S. Lewis. 1993. Mitogen-regulated $\mathrm{Ca}^{2+}$ current of T lymphocytes is activated by depletion of intracellular $\mathrm{Ca}^{2+}$ stores. Proceedings of the National Academy of Sciences, USA. 90:6295-6299. 